Summer 2015

\title{
The Politics of Fiscal Austerity: Democracies and Foresight
}

\author{
Paul L. Posner \\ George Mason University, pposner@gmu.edu
}

Follow this and additional works at: https://www.repository.law.indiana.edu/ijgls

Part of the European Law Commons, International Law Commons, and the Law and Economics

\section{Commons}

\section{Recommended Citation}

Posner, Paul L. (2015) "The Politics of Fiscal Austerity: Democracies and Foresight," Indiana Journal of Global Legal Studies: Vol. 22 : Iss. 2 , Article 7.

Available at: https://www.repository.law.indiana.edu/ijgls/vol22/iss2/7

This Symposium is brought to you for free and open access by the Law School Journals at Digital Repository @ Maurer Law. It has been accepted for inclusion in Indiana Journal of Global Legal Studies by an authorized editor of Digital Repository @ Maurer Law. For more information, please contact rvaughan@indiana.edu.

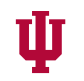

JEROME HALL LAW LIBRARY

INDIANA UNIVERSITY

Maurer School of Law
Bloomington 


\title{
The Politics of Fiscal Austerity: Democracies and Foresight
}

\author{
PAUL L. POSNER ${ }^{*}$
}

\begin{abstract}
Daunting fiscal policy challenges face democratic systems throughout the world. Fiscal austerity in the wake of the Great Recession prompted nations in the Organisation for Economic Co-operation and Development (OECD) to institute major spending cuts and tax increases, increases that caused political and social fallout for years to come. While economies and budgets have improved in the past several years, significant fiscal adjustments lie ahead due to aging populations and the seemingly inexorable growth of health care costs. Faced with larger cohorts of retirees and fewer workers, nations will have to come to grips with a fiscal reality of higher spending and lower revenues for the foreseeable future. This article examines whether and how fiscal austerity measures are politically stabilizing or destabilizing for elected leaders responsible for their imposition. Many would predict that democracies are ill suited to make these hard choices, and certainly regimes have gone down to defeat following the formulation of austerity programs. However, the record is mixed-many regimes have found strategies to mitigate the political fallout and guarantee reelection in the wake of austerity. While traditional incremental and pluralist politics continue to characterize the budgetary strategies of many systems, major policy reforms have risen to the center of policy agendas elsewhere. While the magnitude of the fiscal crisis prompted the adoption of major policy shifts in hard-pressed nations, such reforms were undergirded by a more volatile policy process featuring the emergence of new pathways to power with greater roles for experts and symbolically compelling ideas.
\end{abstract}

* Professor and director of the Master of Public Administration program at George Mason University. This Paper was prepared for the Conference on Law and the Globalization of Austerity at the Maurer School of Law, Indiana University-Bloomington, on September 11 and 12, 2014. I would like to thank Matthew Sommerfeld, a Ph.D. candidate in political science at George Mason University, for his valuable assistance on this paper.

Indiana Journal of Global Legal Studies Vol. 22 \#2 (Summer 2015)

(C) Indiana University Maurer School of Law 


\section{INTRODUCTION}

Advanced nations face nearly unprecedented fiscal challenges, both for the medium and long term. Nearly unparalleled fiscal ambiguity clouds budgeting, as both forces demanding fiscal consolidation and advocating growth and stimulus to invigorate stagnant economies conflict nations. Daunting challenges lie ahead in the next several decades for democratic nations and their leaders. With deficits and debt rising to near-record levels in most nations, the recovery from the recession will still leave significant fiscal gaps that must be addressed. As they cope with the resulting fiscal imbalances, nations will also be dealing with long-term fiscal pressures stemming from the aging of populations and rising health care costs. Unlike previous recessions, the return of strong growth will not eliminate the fiscal gaps facing these nations, but will serve as the prelude to even more difficult and wrenching choices.

The sustainability of national economies will ultimately require a balance between near-term growth and longer-term fiscal consolidation. The question that is now being raised is whether such actions are politically sustainable. Many, in fact, would conclude that fiscal consolidation is an unnatural political act-dooming governments to certain defeat in subsequent elections. Recent elections seem to confirm this: governments have lost power in nine Organisation for Economic Co-operation and Development (OECD) nations that imposed fiscal austerity.. Political failure will bring about economic failure as skeptical markets will rightly lose confidence in fiscal austerity regimes. Ultimately, good economics depends on good politics.

In fact, many analysts and observers have concluded that democratic nations will tend to procrastinate and adopt needed spending and tax reforms only when a market-driven crisis arises to demand action. Yet, waiting for a crisis has significant downsides. Nations that wait for a crisis will face far larger fiscal adjustments. Moreover, the recent political unrest in European nations attests that implementing consolidation in the center of a crisis requires precipitous changes to be instituted in short order, causing untold political and social dislocation and risks to millions of people. ${ }^{1}$

As the OECD begins to emerge from the recession, the central question is whether democratic nations can take proactive leadership before a crisis forces action. A democratic system's capacity to exercise fiscal self-restraint and foresight are among the central issues facing

1. See generally LORENZO BINI SMAGHI, AUSTERITY: EUROPEAN DEMOCRACIES AGAINST THE WALL (2013). 
advanced systems today. This article examines the politics of fiscal consolidations in OECD nations in recent years, and assesses whether and how leaders attempted to resolve the tensions between the fiscal and electoral imperatives they face.

\section{Deficit AND DeBt Position OF OECD MEMBER COUNTRIES}

The Great Recession has had a staggering impact on fiscal policy. Average national deficits for advanced economies spiked from 3.9 percent of gross domestic product (GDP) in 2008 to a high of 8.3 percent in 2010, as shown in Table 1 below. General government debt rose from 80 percent of GDP for advanced economies in 2008 to over 107 percent in $2014 .^{2}$

Table 1: Fiscal balances, advanced nations: 2008-2015

\begin{tabular}{|c|c|c|c|c|c|c|c|c|}
\hline & \multirow[b]{2}{*}{2008} & \multirow[b]{2}{*}{2009} & \multirow[b]{2}{*}{2010} & \multirow[b]{2}{*}{2011} & \multirow[b]{2}{*}{2012} & \multirow[b]{2}{*}{2013} & \multicolumn{2}{|c|}{ Projections } \\
\hline & & & & & & & 2014 & 2015 \\
\hline \multicolumn{9}{|c|}{ Overall Balance (percent of GDP) } \\
\hline $\begin{array}{l}\text { World } \\
\text { Advanced Economies } \\
\text { Euro Area } \\
\text { France } \\
\text { Germany } \\
\text { Greece } \\
\text { Ireland } \\
\text { Itahy } \\
\text { Portugal } \\
\text { Spain } \\
\text { Japan } \\
\text { United Kingdom } \\
\text { Others }\end{array}$ & $\begin{array}{l}-2.5 \\
-3.9 \\
-2.1 \\
-3.3 \\
-0.1 \\
-9.9 \\
-7.3 \\
-2.7 \\
-3.7 \\
-4.5 \\
-4.1 \\
-5.0 \\
2.5\end{array}$ & $\begin{array}{r}-7.8 \\
-9.5 \\
-6.4 \\
-7.6 \\
-3.1 \\
-15.6 \\
-13.8 \\
-5.4 \\
-10.2 \\
-11.1 \\
-10.4 \\
-11.3 \\
-0.9\end{array}$ & $\begin{array}{r}-6.3 \\
-8.3 \\
-6.2 \\
-7.1 \\
-4.2 \\
-10.8 \\
-30.5 \\
-4.4 \\
-9.9 \\
-9.6 \\
-9.3 \\
-10.0 \\
-0.2\end{array}$ & $\begin{array}{r}-4.8 \\
-6.9 \\
-4.2 \\
-5.3 \\
-0.8 \\
-9.6 \\
-13.1 \\
-3.7 \\
-4.3 \\
-9.6 \\
-9.8 \\
-7.8 \\
0.4\end{array}$ & $\begin{array}{r}-4.4 \\
-6.2 \\
-3.7 \\
-4.8 \\
0.1 \\
-6.3 \\
-8.2 \\
-2.9 \\
-6.5 \\
-10.6 \\
-8.7 \\
-8.0 \\
0.5\end{array}$ & $\begin{array}{r}-3.8 \\
-4.9 \\
-3.0 \\
-4.2 \\
0.0 \\
-2.6 \\
-7.4 \\
-3.0 \\
-4.9 \\
-7.2 \\
-8.4 \\
-5.8 \\
0.2\end{array}$ & $\begin{array}{r}-3.5 \\
-4.3 \\
-2.6 \\
-3.7 \\
0.0 \\
-2.7 \\
-5.1 \\
-2.7 \\
-4.0 \\
-5.9 \\
-7.2 \\
-5.3 \\
0.4\end{array}$ & $\begin{array}{l}-3.0 \\
-3.6 \\
-2.0 \\
-3.0 \\
-0.1 \\
-1.9 \\
-3.0 \\
-1.8 \\
-2.5 \\
-4.9 \\
-6.4 \\
-4.1 \\
0.6\end{array}$ \\
\hline \multicolumn{9}{|c|}{2008 System of National Accounts (SNA) } \\
\hline $\begin{array}{l}\text { Canada } \\
\text { United States } 2\end{array}$ & $\begin{array}{l}-0.3 \\
-7.8\end{array}$ & $\begin{array}{r}-4.5 \\
-14.7\end{array}$ & $\begin{array}{r}-4.9 \\
-12.5\end{array}$ & $\begin{array}{r}-3.7 \\
-11.0\end{array}$ & $\begin{array}{l}-3.4 \\
-9.7\end{array}$ & $\begin{array}{l}-3.0 \\
-7.3\end{array}$ & $\begin{array}{l}-2.5 \\
-6.4\end{array}$ & $\begin{array}{l}-2.0 \\
-5.6\end{array}$ \\
\hline
\end{tabular}

Source: Int'l Monetary Fund, Fiscal Monitor: Public Expenditure Reform, at 3 (Apr. 2014).

These burgeoning deficits and debt have prompted twenty-five OECD nations to adopt plans to institute fiscal consolidation amounting to nearly 6 percent of GDP from 2009 to 2013. Two-thirds of the reduction in balances would come from the spending side, with the remainder accounted for by tax increases. ${ }^{3}$

2. Int'l Monetary Fund, Public Expenditure Reform: Making Difficult Choices, FISCAL MONITOR 5 (Apr. 2014).

3. Mario Marcel, Budgeting for Fiscal Space and Government Performance Beyond the Great Recession, 13 OECD J. ON BUDGETING 9, 15 (2014). 
While all OECD nations experienced fiscal stress from the Great Recession, their experiences varied considerably. OECD has grouped nations into four categories, which illustrate the large variation of fiscal pressures felt across advanced nations:

Group 1: Fiscal foresight-nations that brought substantial surpluses into the crisis period such as Sweden and Canada;

Group 2: Fiscal victims-nations who were fiscal victims requiring bailouts such as Greece and Spain;

Group 3: Fiscal mitigation-nations whose stronger economies buffered the full impact of the crisis such as Germany; and

Group 4: Fiscal immune-nations with deep deficits immune from debt market pressures such as the United States and Japan. ${ }^{4}$

The data in Table 2 show the different fiscal consequences the financial crisis wrought for nations in each grouping. ${ }^{5}$ Nations in the fiscal foresight group faced the least change in balances and debt, while nations in the fiscal victim group experienced the greatest increase in deficits. The nations in the fiscal immune group, however, saw the largest increases in gross debt, with Japan crossing the 200 percent of GDP threshold.

4. Id. at 13.

5. Group 1 countries include: Australia, Canada, Finland, Korea, New Zealand, and Sweden. Group 2 countries include: Greece, Hungary, Iceland, Ireland, Italy, Portugal, and Spain. Group 3 countries include: Austria, Belgium, Estonia, France, Germany, Luxembourg, the Netherlands, the Slovak Republic, and Slovenia. Group 4 countries include: Japan, Switzerland, the United Kingdom, and the United States. Id. at 14. 
Table 2: General government fiscal behavior by country groupings: 2009-2013

\begin{tabular}{|l|l|l|l|}
\hline & $\begin{array}{c}\text { Change in } \\
\text { Underlying Balance }\end{array}$ & $\begin{array}{c}\text { Change in } \\
\text { Primary } \\
\text { Spending }\end{array}$ & $\begin{array}{c}\text { Change } \\
\text { in Gross } \\
\text { Debt }\end{array}$ \\
\hline Group 1 & 2.37 & -3.52 & 1.71 \\
\hline Group 2 & 7.95 & -5.14 & 13.41 \\
\hline Group 3 & 2.85 & -2.29 & 12.16 \\
\hline Group 4 & 2.75 & -2.87 & 24.21 \\
\hline Total & 3.32 & -3.16 & 17.66 \\
\hline
\end{tabular}

Source: Mario Marcel, Budgeting for Fiscal Space and Government Performance Beyond the Great Recession, 13 OECD J. ON BUDGETING 9, 14 (2014).

While the short-term fiscal deficits are difficult enough, many OECD nations face longer-term fiscal consolidation requirements to stabilize their debt-to-GDP ratios by 2025. According to these calculations, Japan has the highest fiscal consolidation requirements beyond 2011 followed by Ireland, the United States, and the United Kingdom. The data presented in Figure 1 suggest that fiscal consolidation will be on the agenda of many advanced nations long after the financial crisis is over. 
Figure 1: Longer-term fiscal consolidation needs

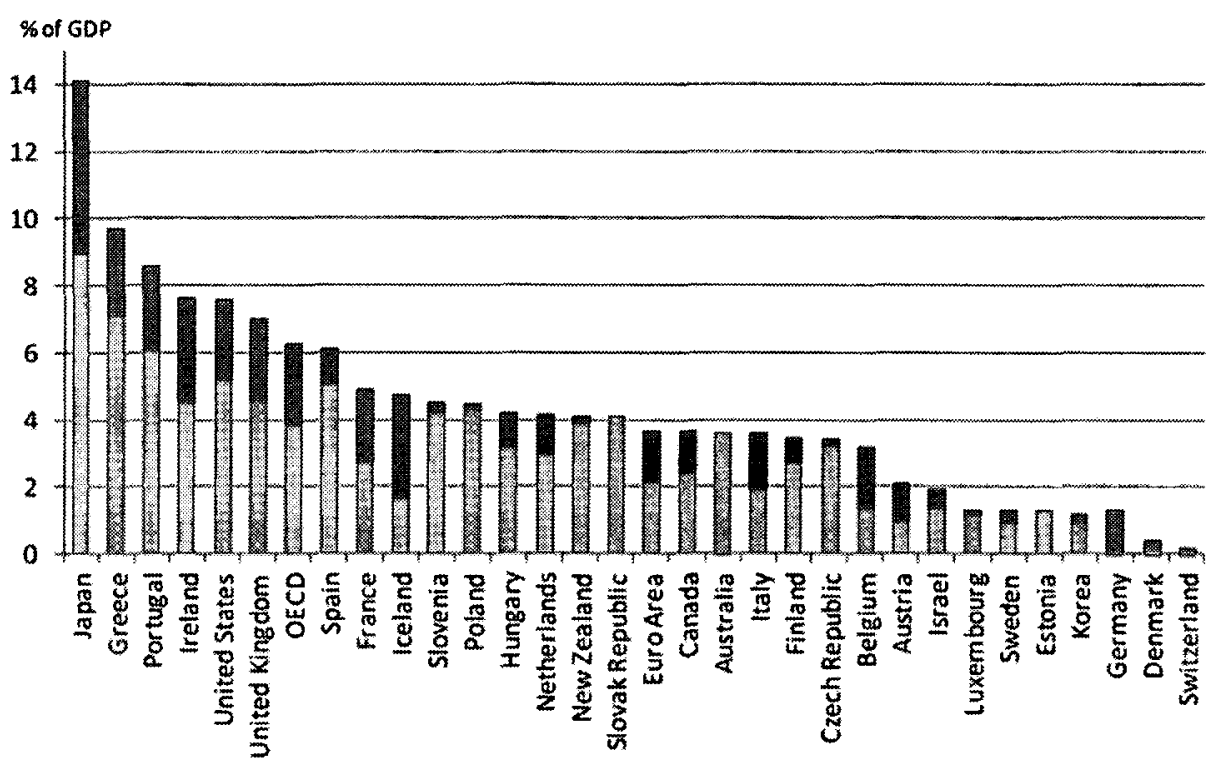

Average consolidation to stabilise debt

Additional consolidation to lower debt

Source: ORG. FOR ECON. CO-OPERATION \& DEV., OECD ECONOMIC OUTLOOK No. 91, at 207-08 (2012).

\section{CAN DEMOCRACIES TAKE EARLY ACTION?}

The foregoing suggests that leaders in OECD nations face a daunting array of short- and long-term fiscal challenges. Fiscal gaps are daunting, perhaps more daunting than at any time in postwar history. According to recent International Monetary Fund (IMF) data, the world's deficits will remain 3 percentage points larger in 2015 than in 2007 - even though output gaps would have been closed. Beyond the short-term, the United States and many European nations face the longer-term problems of the unsustainable costs posed by an aging society and rising health care costs.

Once the economies of OECD nations improve, the fiscal choices will once again become a central and appropriate issue for national leaders to address. As they face these choices, serious questions will be answered about whether advanced democracies have the political capacity to make the hard fiscal choices early enough to avoid a future featuring serious economic and fiscal shortfalls and precipitous and divisive political choices. Herbert Stein, chair of the Council of Economic 
Advisers under Presidents Richard Nixon and Gerald Ford, ${ }^{6}$ famously said: "[i]f something cannot go on forever, it will stop." But there is a corollary-how it stops matters.

Timely and early action can tame the magnitude of fiscal deficits by intercepting the growth of government interest costs before they crowd out public fiscal flexibility and private markets. In the United States, long-term budget models show that the failure to curb fiscal deficits over the next several decades will enable interest costs to become the largest "program" in the budget, exceeding health care and social security. ${ }^{8}$ Politically, timely action on fiscal problems yields significant dividends in providing the members of the public time to make adjustments to their own retirement and savings plans and their expectations about the role of government in their lives. If nations wait until a market crisis forces their hands, their economies and citizens will pay a steep price. As we have seen recently in nations like Greece, bond markets can suddenly force nations to make delayed reforms in major entitlements and tax policies during the trough of a painful recession. ${ }^{9}$ While promising eventual economic load shedding, ill-timed fiscal consolidations have the potential to be self-defeating, prompting a vicious cycle of continued economic decline and short-term fiscal erosion.

Other nations have undergone either outright defaults or serious flirtations with insolvency for which they paid a long-term economic and political price. According to one estimate, more than ninety nations have in fact defaulted on their debt over the past two centuries. ${ }^{10}$ Many other nations at the financial brink managed to avoid default, but nonetheless experienced economic shocks and policy upheavals that caused rapid erosion of economic wealth and incomes.

The effects of such a shock are wide-ranging. Currencies will experience rapid depreciation, ushering in spikes in inflation and interest rates. As the pressure to meet fiscal commitments increases, some governments might resort to printing more money to lessen the

6. Paul Krugman, This Can't Go On, N.Y. TIMES, Nov. 4, 2003, http://www.nytimes. com/2003/11/04/opinion/this-can-t-go-on.html.

7. Herbert Stein, What I Think: Essays on Economics, Politics, AND LifE 32 (1998).

8. Cong. Budget Office, Pub. No. 4933, The 2014 Long Term Federal Budget OUTLOOK 3 (2014).

9. Zsolt Darvas \& Olga Tschekassin, Poor and Under Pressure: The Social Impact of Europe's Fiscal Consolidation, 4 BRUEGEL POL'y CONTRIBUTION 2, 7 (2015).

10. Anne Krueger, Op-Ed., Deberian poder declararse en quiebra los paises como Argentina?, EL País, Jan. 18, 2002, at 16. 
debt burden, creating massive inflation. In either case, economic growth would collapse and the standard of living would decline. ${ }^{11}$

Implementing the fiscal cure-spending cuts and tax increases-in the throes of a crisis would cause painful adjustments as well, at least in the near term. Much-delayed changes have to be implemented abruptly with little deliberation or debate. Major changes to entitlements and tax benefits that have become ingrained have to occur almost overnight, as national leaders strain mightily to regain the confidence of credit markets and other investors throughout the world. ${ }^{12}$

Eventually, such actions would probably restore economic growth, tame inflation, and cut interest rates, but not after taking incomes and benefits below levels that most of us have come to expect. Early action on fiscal pressures could have mitigated extreme cuts and enabled adjustments to be phased in over many years, but an economic and financial crisis no longer affords this luxury. ${ }^{13}$

Ultimately, nations undertaking major fiscal cures in the throes of an economic crisis can usher in political instability. Since consolidations can exacerbate both deficits and downturns, they can be expected to give rise to public resistance and political unrest. The legitimacy of deep cuts is particularly vulnerable to reversal when governments introduce cuts with little advance public education or when the public perceives consolidation to be externally imposed.

Indeed, of the fourteen European crisis-hit nations that had elections from 2009 to 2012, nine of them deposed the sitting government. The foregoing shows that the governments' defeat came during a time of high unemployment coupled with austerity measures. ${ }^{14}$

Spain (unemployment rate in 2012: 23 percent)
Mariano Rajoy's conservatives defeated the Socialist
government in November 2011, marking their first
electoral victory since 2000 .

11. See Leonard E. Burman et al., Catastrophic Budget Failure, 63 NAT'L TAX J. 561, 575-79 (2010) (describing the macroeconomic effects of debt crises).

12. Paul L. Posner, Will it TAKe a Crisis? 13 (The Pew Charitable Trusts, 2011).

13. See CONG. BUDGET OFFICE, supra note 8, at 14 ("Several years ago, when federal debt was below 40 percent of GDP, the government had some flexibility to respond to the financial crisis and severe recession by increasing spending and cutting taxes to stimulate economic activity, providing public funding to stabilize the financial sector, and continuing to pay for other programs even as tax revenues dropped sharply because of the decline in output and income.").

14. See Anthony Faiola, French, Greek Voters Deal Blow to Austerity, WASH. PoST, May 7, 2012, at A01. 
Greece (unemployment rate in 2012: 20.6 percent) Socialist leader George Papendreou resigned in November 2011 and was replaced by Independent Lucas Papedmos, who was charged with bringing various factions together in response to the crisis.

Portugal (unemployment rate in 2012: 12.6 percent) The center-left Socialist government, led by Jose Socrates, was voted out of power in June 2011 and replaced by Aníbal Cavaco Silva from the Social Democratic Party.

Ireland (unemployment rate in 2012: 14.2 percent) Prime Minister Brian Cowen resigned just weeks prior to the February 2011 election, and his center-right Party, Fianna Fáil, was overtaken by Enda Kenny, leader of the centrist Party Fine Gael.

France (unemployment rate in 2012: 10 percent) Socialist François Hollande narrowly defeated conservative Nicolas Sarkozy in May 2012 to give the Socialists their first electoral victory since 1997.

Italy (unemployment rate in 2012: 9.2 percent) In November 2011, Silvio Berlusconi, of the center-right coalition "The People of Freedom," resigned. In April 2013, Independent Giorgio Napolitano was elected with a comfortable margin of victory.

United Kingdom (unemployment rate in 2012: 7.8 percent) In May 2010, Conservative Party leader David Cameron defeated Labor's Gordon Brown in a coalition with the Liberal party, marking the first electoral victory for the Conservatives since 1992.

Denmark (unemployment rate in 2012: 7.6 percent) In September 2011, the center-left coalition, led by Helle Thorning-Schmidt, narrowly defeated the center-right coalition.

Finland (unemployment rate in 2012: 7.9 percent) In April 2011, the Center Party, which had previously won 
two consecutive elections, was defeated and replaced by the National Coalition Party.

\section{ERosion of FAith IN THE POLITICAL EFFiCACY OF DEMOCRATIC INSTITUTIONS}

\section{A. Democratic Elections as a Disincentive for Fiscal Foresight}

Notwithstanding the overwhelming advantages of early action on fiscal challenges, many observers have concluded that democratic systems and leaders are incapable of acting with foresight on fiscal problems. Many of the most sophisticated commentators think it will take a crisis for nations to collectively face the hard choices needed to be made on the spending and tax sides of the budget. In this view, foresight is a politically unnatural act for elected officials who focus more on their next election than on the fiscal prospects facing the nation twenty years from now. Drazen and Easterly conclude that the hypothesis that a crisis is necessary to induce significant reform has become the new orthodoxy. ${ }^{15}$ In the United States, some of our leading fiscal observers have voiced this dour outlook. Leonard Burman, a leading public finance scholar and public official has concluded:

The basic problem is that policymakers want to make people happy, which means more spending and lower taxes. As long as interest rates stay low and the public does not express a strong aversion to deficits, there is little cost to political pandering. Politicians face the same kind of incentive for short-term actions that may be detrimental over the long-term as corporate executives do. Corporate CEOs are rewarded financially for boosting short-term profits, even if they harm the company over the long-term. Political leaders perceive that their reelection depends on short-term results, even if the short-term expedients may be disastrous over the long-term. ${ }^{16}$

The perceived conflict between the electoral imperative bearing down on public officials and the fiscal responsibility imperative is not

15. Allan Drazen \& William Easterly, Do Crises Induce Reform? Simple Empirical Tests of Conventional Wisdom, 13 ECON. \& PoL. 129, 153-56 (2001) (describing evidence supporting the "strong version of the crisis-induces-reform hypothesis").

16. Burman et al., supra note 11 , at 566. 
only quite prevalent among policy leaders, but it has deep academic roots. Public-choice theorists have contributed their own theoretical justification. The behavioral assumption behind this view is that public officials are motivated by self-interest to pursue private gain at the expense of the public interest. Buchanan attempts to demonstrate how bureaucrats and politicians alike will force government budgets to be higher than they should be to increase their own "political incomes."17 Agents use their superior information as well as their superior political organization and intensity over principals (i.e., the electorate) to push up spending and perpetuate a larger public sector. Government is a monopolist and not a neutral responder to demands from the public. ${ }^{18}$ Buchanan and Tullock argue that politicians are incapable of fixing the deficit. Elections make them shortsighted and irresponsible, and only a major crisis or constitutional amendment will force fiscally responsible actions. ${ }^{19}$

Beyond public-choice theory, other political scientists have long observed that the common pool problem creates asymmetry between those benefitting from narrow benefits and those paying the costs. As James Wilson notes, "clientele" politics promote the expansion of government benefits because those enjoying concentrated benefits have a greater incentive to mobilize than the broad publics paying for these programs. But efforts to unwind these programs are undermined by "entrepreneurial politics" where those bearing the concentrated costs of cutbacks have greater incentive to voice their concerns than do broad publics who stand to realize diffuse gains. ${ }^{20}$ Many conclude that this incentive structure fosters deficits and curbs efforts to balance budgets because of the bias toward higher spending implied in this asymmetry. ${ }^{21}$ This asymmetry of interests is reflected in an asymmetry in mobilization. The most intense interests with the greatest incentives to mobilize are the narrow groups benefitting from higher spending or

17. See James M. Buchanan, Why Does Government Grow?, in BUDGETS AND BurEaUCRATS: THE SOURCES OF GOVERNMENT GROWTH 3, 13 (Thomas E. Borcherding ed., 1977).

18. See William C. Mitchell, Fiscal Behavior of the Modern Democratic State: Public Choice Perspectives and Contributions, in PUBliC Policy THeORIES, Models, AND CONCEPTS 125, 129 (Daniel C. McCool ed., 1995).

19. See generally James M. Buchanan \& GoRdon Tullock, The Calculus of CONSENT, LOGICAL FOUNDATIONS OF CONSTITUTIONAL DEMOCRACY (1962) (using economic theory to study democratic decisionmaking from the perspective of the individual).

20. See James Q. Wilson, THe Politics of REgulation 357, 358-68 (James Q. Wilson ed., 1980).

21. See, e.g., Xavier Debrun, Democratic Accountability, Deficit Bias and Independent Fiscal Agencies (Int'l Monetary Fund, Working Paper 11/173, 2011) (illustrating features of independent fiscal agencies and their need to incorporate the political nature of fiscal policy). 
lower revenues, not the broader public who has to finance the costs in one way or the other.

The bias against early action on deficits is reinforced by the steep discount rates that political leaders are said to adopt. Political leaders are shortsighted and have even less incentive to promote sacrifice among current taxpayers for the benefit of future taxpayers or public officials. The election cycles are often two to four years in most democracies, reinforcing the short-term bias of elected officials.

\section{B. The Purported Role of Economic Crises in Reestablishing Fiscally Responsible Government}

From these perspectives, a crisis appears to be the only way that the discounting problem and the asymmetries between narrow and broad interests can be addressed. First, a crisis overcomes the discounting problem by transforming the problem into one that affects current taxpayers. While current stakeholders may lose specific benefits from deficit reduction, they also realize immediate gains through the rescue of the broader economy, the crisis of which has made rescue a compelling and immediate concern. A crisis rebalances the intensity between narrow beneficiaries and broader taxpayers by making the diffuse costs of current policies more salient and visible to broader publics. It also makes the projected benefits from spending cuts and tax increases more compelling as well. Accordingly, a crisis succeeds in reversing the mobilization bias from the narrow beneficiaries of government programs to the broader publics.

It is important to define what this article means by a crisis. Given the absence of any commonly accepted threshold beyond which a problem merits categorization as a crisis, it may be said-as "social constructionists" stress-that any crisis is to some extent a creation of the language used to depict it. The definition and response to a crisis involves a contest between competing frames regarding severity, causes, responsibility, and implications. ${ }^{22}$

Nonetheless, for purposes of this article, the author defines a crisis as an exogenous event or "shock" bearing down on all actors of the system that requires some kind of policy response. In its pure form, a fiscal crisis would consist of a market-induced shock where credit markets react by actions that cause immediate harm to the economy and to the prospects of financing government debt. This narrower definition helps control for endogeneity where political leaders already

22. Daniel Nohrstedt \& Christopher M. Weible, The Logic of Policy Change after Crisis: Proximity and Subsystem Interaction, 1 RISKS, HAZARDS \& CRISIS PUB. POL'Y 1, 6 (2010). 
committed to proactive fiscal policy contrive crises to mobilize support for their pre-existing positions. For instance, in the United States, policymakers brought about a series of "fiscal cliffs" that required leaders to make spending cuts and tax increases to avoid a series of across-the-board cuts and tax increases. In January of 2013, leaders instituted tax increases on the wealthy to avoid across-the-board tax increases on the mass populace. Later during the same year, the leaders' failure to enact spending cuts precipitated a series of extensive across-the-board cuts and resulted in a government shutdown for sixteen days-in effect, the government "jumped off" the fiscal cliff. These kinds of crises would not fall under the more rigorous definition of crises used in the remainder of this article.

\section{ACHIEving the Politically ImPROBABle: A FIVE-Nation Study}

Notwithstanding the reigning pessimism about democracies and deficits, many advanced nations have in fact undertaken significant fiscal consolidations in recent years. One OECD study found that from 1978 through 2007, there were eighty-five fiscal consolidation episodes in twenty-four OECD nations that improved the cyclically adjusted fiscal balance. Most of these consolidation episodes were of short duration and led to only modest gains in fiscal balances. As shown in Figures 2 and 3 below, however, several episodes lasted over longer periods and achieved considerably greater fiscal consolidation. ${ }^{23}$

23. Stéphanie Guichard et al., What Promotes Fiscal Consolidation: OECD Country Experiences 8 (Org. for Econ. Co-Operation \& Dev., Econ. Dep't, Working Paper No. 553, 2007), available at http://dx.doi.org/10.1787/180833424370. 
Figure 2: Frequency and size of fiscal consolidations (1978-2007)

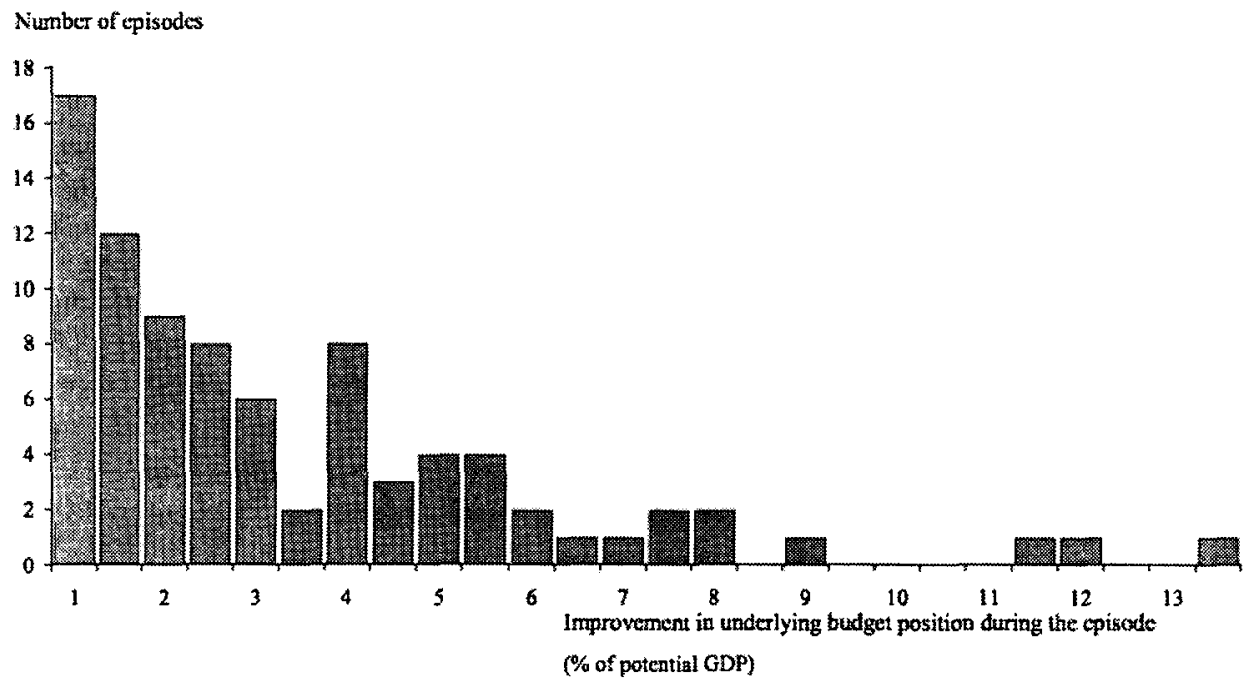

Source: Stephanie Guichard et al., What Promotes Fiscal Consolidation: OECD Country Experiences 8 (Org. for Econ. Co-Operation \& Dev., Econ. Dep't, Working Paper No. 553, 2007), available at http://dx.doi.org/10.1787/180833424370.

Figure 3: Frequency and duration of fiscal consolidations (19782007)

Number of episodes

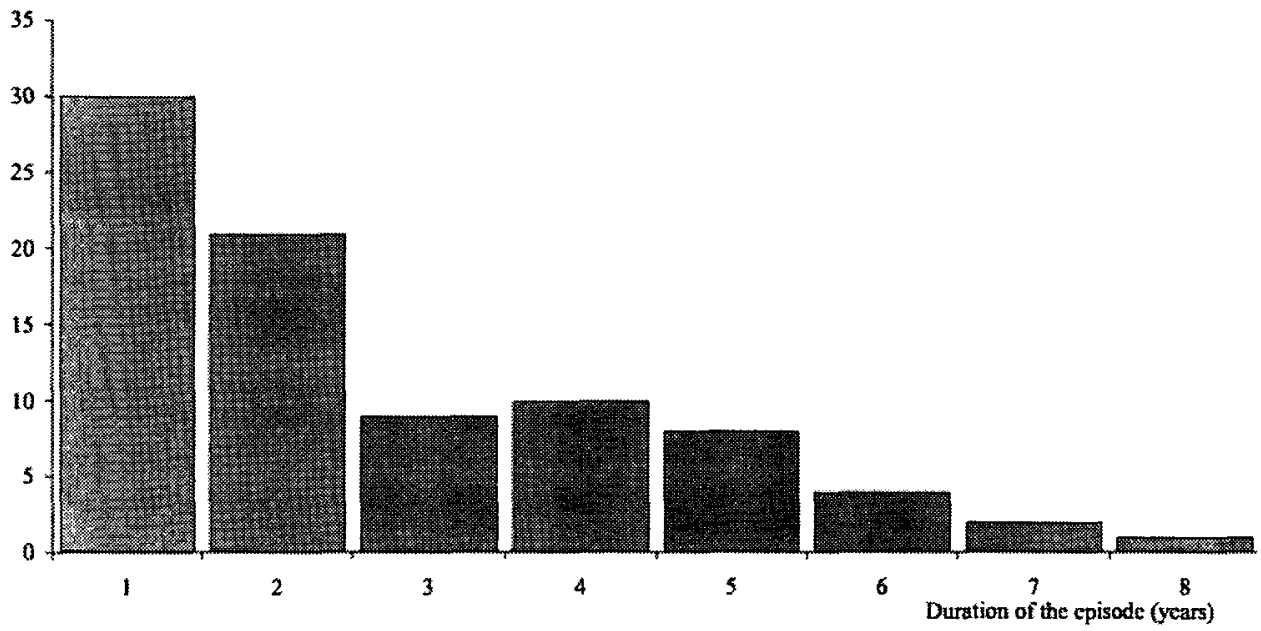

Source: Stephanie Guichard et al., What Promotes Fiscal Consolidation: OECD Country Experiences 8 (Org. for Econ. Co-Operation \& Dev., Econ. Dep't, Working Paper No. 553, 2007), available at http://dx.doi.org/10.1787/180833424370. 
A separate OECD study examined the incidence and evolution of large fiscal consolidation episodes. ${ }^{24}$ It found thirteen cases of deficit reduction between 1980 and 2000 where deficits were reduced from 8 to 1 percent of GDP within five years.

Economist Henry Aaron notes that many advanced nations have achieved even more significant swings in the primary balance in the years before the 2008 financial crisis. The following table illustrates that many nations, including the United States, have achieved significant and sustained reductions of deficits and debt. ${ }^{25}$

Table 3: Fiscal swings for major consolidations in the OECD

\begin{tabular}{|l|l|l|}
\hline \multicolumn{1}{|c|}{ Nation } & \multicolumn{1}{|c|}{ Period } & \multicolumn{1}{c|}{$\begin{array}{l}\text { Fiscal Swing as } \\
\text { Percent of GDP }\end{array}$} \\
\hline Australia & $1992-1999$ & 7.5 \\
\hline Canada & $1992-2000$ & 11.1 \\
\hline Finland & $1992-2000$ & 12.3 \\
\hline New Zealand & $2000-2006$ & 5.9 \\
\hline Sweden & $1993-2000$ & 14.9 \\
\hline United Kingdom & $1993-2000$ & 11.7 \\
\hline United States & $1992-2000$ & 7.4 \\
\hline
\end{tabular}

Source: Henry J. Aaron, How to Think About the U.S. Budget Challenge, 29 J. PoL'Y ANALYSIS \& MGMT. 883, 889 (2010).

The question posed for OECD nations is how to learn from these past episodes and help budget officials cope with wrenching fiscal choices today. Research is just beginning to be published on the experience of nations with austerity in the wake of the 2008 financial crisis. ${ }^{26}$ The challenges of and responses to the recent financial crisis are critical to understanding the prospects of democratic nations.

Nevertheless, an examination of how nations addressed such fiscal challenges in previous episodes can be revealing because we have had a longer period to observe national policy responses. Were the nations from the past able to definitively face structural deficits and resolve them in ways that were both economically and politically sustainable? Were the fiscal actions taken done under the pressure of an exogenous crisis or were other factors primarily responsible for pushing fiscal

24. Hansjörg Blöchliger et al., Fiscal Consolidation: Part 4. Case Studies of Large Fiscal Consolidation Episodes (Org. for Econ. Co-Operation \& Dev., Econ. Dep't, Working Paper No. 935, 2012), available at http://dx.doi.org/10.1787/5k9fdf5xptlq-en.

25. See Henry J. Aaron, How to Think About the U.S. Budget Challenge, 29 J. PoL'Y ANALYSIS \& MGMT. 883, 889 (2010) (showing reduction in fiscal gap for selected nations during various periods). 
consolidation onto the policy agenda? Were the economies of those nations made better off not only in the short-term, but also in the longer term? As political leaders of today face seemingly no-win choices between austerity and growth, how did political officials fare with the voters when they implemented previous consolidations?

\section{A. Analytical Approach}

This article reviews the vast literature on fiscal consolidation to assess the extant research on these questions. In addition, it reviews the experiences of a set of nations that achieved significant consolidation and sustained surpluses for more than six years consecutively before the financial crisis, as shown in Table 4.

Table 4: OECD surplus nations 2000-2008

\begin{tabular}{|l|l|}
\hline \multicolumn{1}{|c|}{ Nation } & \multicolumn{1}{c|}{ Years in Surplus } \\
\hline Australia & 9 \\
\hline Canada & 6 \\
\hline Denmark & 8 \\
\hline Finland & 9 \\
\hline Korea & 9 \\
\hline Luxembourg & 8 \\
\hline New Zealand & 9 \\
\hline Norway & 9 \\
\hline Sweden & 7 \\
\hline
\end{tabular}

Source: Paul Posner \& Matthew Sommerfeld, The Politics of Fiscal Austerity: Democracies and Hard Choices 12 (Org. for Econ. Co-Operation \& Dev., Governance and Territorial Dev. Directorate 2012), available at http://www.oecd.org/officialdocuments/publicdisplay documentpdf $/$ cote=GOV/PGC/SBO $\% 282012 \% 294 \&$ doclanguage=en .

The author examined the experiences of four of these nations in depth: Australia, Canada, New Zealand and Sweden. These nations' consolidations were perhaps the deepest and among the most longlasting consolidations of the OECD members. In addition, the United States was added since it sustained consolidation for ten years in the

26. See, e.g., Walter Kickert, Tiina Randma-Liiv \& Riin Savi, The Politics of Fiscal Consolidation in Europe: A Comparative Analysis (June 14, 2014), available at http://www.cocops.eu/wp-content/uploads/2013/10/WP7-trend-report_final.pdfops.eu/wpcontent/uploads/2013/10/WP7-trend-report_final.pdf. 
1990s, ultimately running surpluses for four of those years. ${ }^{27}$ The United States illustrates the experience of a presidential separation of powers system compared to the other parliamentary systems.

For each of these five nations, the author drew on interviews and secondary documents to show how the following issues affected the initiation, intensity, and political sustainability of consolidations: trigger for consolidation, economic context, political competition among the parties, the timing of consolidation in the electoral cycle, the composition of consolidation initiatives, the strategies pursued to achieve shared sacrifice, and the impact of consolidation on debt and GDP. Spreadsheets showing how the nations were arrayed for each of these dimensions are attached as Appendix $I$ to this article. The following sections discuss the findings on each of these variables based both on a synthesis of the literature and on the five case studies.

\section{B. Impetus}

Fiscal consolidation involves the allocation of sacrifice across contending groups and interests within each nation. Accordingly, it is not surprising that many nations require a compelling trigger to bring about deficit reduction. As a general rule, governments undertake fiscal consolidation only when public finances are weak, as measured by rising deficits and debt levels. ${ }^{28}$ In fact, some studies suggest that the gravity of the initial fiscal conditions influences nations to undertake deeper and more prolonged consolidations, which have a greater chance of stabilizing debt in the future. ${ }^{29}$

Large consolidations constitute a form of punctuated equilibrium where the existing policy frameworks undergo transformations that amount to a policy and political earthquake. Median improvement for large consolidations entails improvement of fiscal balance by 7 percent of GDP within five years. ${ }^{30}$ Alesina and colleagues suggest that a crisis

27. Cong. Budget OFfice, The Budget AND ECONOMIC OUTLOOK: 2015 To 2025, at 4 (2015), available at http:/www.cbo.gov/sites/default/files/cbofiles/attachments/49892Outlook2015.pdf.

28. Margit Molnar, Fiscal Consolidation Part 5. What Factors Determine the Success of Consolidation Efforts? 8-9 (Org. for Econ. Co-Operation \& Dev., Econ. Dep't, Working Paper No. 936, 2012).

29. See Martin Larch \& Alessandro Turrini, Received Wisdom and Beyond: Lessons from Fiscal Consolidations in the EU, in EUROPEAN COMMISSION ECONOMIC PAPERS 320, at 16 (2008); Roberto Perotti, Fiscal Policy in Good Times and Bad, 111 Q. J. EcoN. 1399, 1424-31 (1999).

30. Blöchliger et al., supra note 24 , at 6 . 
is needed to break a political deadlock or "war of attrition" between opposing parties and interests. ${ }^{31}$

Table 5: Fiscal consolidation triggers for case study nations $(1=$ most important; 3 = least important)

Triggers

\begin{tabular}{lccc}
\cline { 2 - 4 } Country: & Market Crisis & Economic Pressures & Political Blame Avoidance \\
\hline Canada (1993-97) & 2 & 1 & 3 \\
Australia (1994-98) & 3 & 2 & 1 \\
Sweden (1994-97) & 1 & 2 & 3 \\
United States (1990-98) & 3 & 2 & 1 \\
New Zealand (1984-93) & 1 & 2 & 3 \\
\hline
\end{tabular}

Source: Paul Posner \& Matthew Sommerfeld, The Politics of Fiscal Austerity: Implications for the United States, 32 PUB. BUDGETING AND FIN. 32, 37 (2012) (table depicts authors' judgment based on case studies).

The experiences recorded in Table 5 illustrate that external economic crises indeed constituted the formative trigger for consolidation in Sweden and New Zealand. Sweden faced economic pressures that triggered a recession and banking crisis in the early 1990s. Economic growth was negative from 1991 to 1993, and registered unemployment increased dramatically from about 2 percent in 1990 to over 8 percent in 1993. The economic slowdown and banking bailout had dramatic fiscal effects that led to a sharp increase in budget deficits, which peaked at over 12 percent of GDP in $1993 .{ }^{32}$

During 1994 and early 1995, Canada's fiscal outlook deteriorated quickly, although it did not reach the dire straits that Sweden experienced. The situation worsened due to a sharp rise in interest rates arising partly from concerns in the international investment community about Canada's large debt burden. Following the economic crisis experienced by Mexico, investors shifted some of their assets out of Canada, pushing up interest rates, lowering the value of the Canadian dollar. This asset shift further pushed up Canadian interest rates, pushed down the Canadian dollar, and prompted Moody's to put the nation on a credit watch. With general government debt approaching 100 percent of GDP, foreign investors demanded higher interest rates. ${ }^{33}$

31. See Alberto Alesina \& Roberto Perotti, Fiscal Expansions and Fiscal Adjustments in OECD Countries 21 (Nat'l Bureau of Econ. Research, Working Paper No. 5214, 1995).

32. U.S. Gov'T ACCOUNTABILITY OFFICE, GAO/AIMD-00-23, BudGET SuRPLUSES: EXPERIENCES OF OTHER NATIONS AND IMPLICATIONS FOR THE UNITED STATES 176 (1999).

33. Canada Government Debt to GDP 1988-2015, Trading Econ., http://www. tradingeconomics.com/canada/government-debt-to-gdp (last visited June 10, 2015). 
Of course, deficits and debt do not cause a crisis by themselvespolitical actors do by using economic statistics to frame policy debates. Thus, in Canada, as the economy worsened, the crisis reached a boiling point when the nation's pride was wounded by a Wall Street Journal editorial likening the nation to a banana republic.

In some cases, however, even relatively modest fiscal imbalances can lead to national alarm and fiscal consolidation. The labeling of these imbalances as a "crisis" in nations illustrates how that overworked term is often socially constructed. For instance, Australia redoubled its efforts for consolidation after the recession of the early 1990s. By international standards, fiscal imbalances were relatively modest, with deficits peaking at 3.6 percent of GDP in 1992, and growth resuming in $1993 .{ }^{34}$ Thus, a sharp trigger or crisis did not prompt renewed action in Australia. Rather, it was broader economic concerns that the deficits symbolized that troubled elites. This included the shadow cast by the original economic and fiscal crisis of the mid-1980s and the reliance of the Australian economy on foreign sources of capital to finance private investment. In the post-financial-crisis era, the fiscal anxiety continues, as the Labor government uses crisis metaphors to justify a return to surpluses. In nations like Australia, budget surpluses have come to serve as a symbolic metaphor for the competence of the governmentthe single most important "acid test" of a government's economic credentials. $^{35}$

In the United States, serious consolidation began in 1990 and lasted through 2001. High interest rates alarmed both the central bank and the business community, but there was certainly no market crisis bearing down on the nation. Lacking a compelling market crisis, federal officials developed fiscal rules under the Gramm Rudman Hollings budget regime in the 1980s, which threatened to impose across-theboard budget cuts of $\$ 100$ billion in 1990.36 Even without a crisis, the perceived political threat posed to President George H.W. Bush from the specter of these cuts and a slowing economy were sufficient to prompt him to renege on his campaign pledge to avoid new taxes. ${ }^{37}$

34. John Wilkinson, Australian Federal and State Budgets-An Overview 6 (N.S.W. Parliamentary Library Research Serv., Briefing Paper No. 2/10, 2010).

35. Lewis Hawke \& John Wanna, Australia After Budgetary Reform: A Lapsed Pioneer or Decorative Architect?, in THE REALITY OF BUDGETARY REFORM IN OECD NATIONS 65, 81 (John Wanna et al. eds., 2010).

36. See Gramm-Rudman-Hollings Balanced Budget Act of 1985, Pub. L. No. 99-177, 99 Stat. 1037, 1039, 1043-44 (1985) (directing that the congressionally-mandated maximum deficit amount not be exceeded).

37. See Ctrs. on the Pub. Serv., George Mason Univ., Looking Back to Move FoRWARD: THE 1990 BUdGET SUMMIT REvisited 7 (2013) ("Hoping to forge an agreement before sequestration, President Bush began meeting with top congressional leaders in 
Progress toward fiscal consolidation is iterative and nonlinear. Four of the five nations among our case studies had undertaken consolidations in earlier decades. Australia and New Zealand realized substantial fiscal reforms in this earlier period before deep recessions undermined their gains. ${ }^{38}$ Sweden and Canada also experienced consolidations in this earlier decade, which were not as successful as their 1990s initiatives. ${ }^{39}$ This history suggests that fiscal consolidations are path dependent and build on the previous experiences of nations, both good and bad.

Some nations like Canada learned lessons from the failure to sustain fiscal progress in the prior decade that they applied to their more successful 1990s initiative. As overoptimistic assumptions eroded the 1980s deficit reduction, for instance, the new Liberal government in 1994 was determined to use deliberately cautious, "prudent" economic assumptions. In Sweden, the government learned that to sustain its gains, it must adopt a three-year spending cap and a policy goal of sustaining surpluses when economic growth is expanding.

\section{AUSTERITY AND ECONOMIC GROWTH}

Considerable debate rages today about the alleged tension between fiscal austerity and growth. Certainly, macroeconomic theory explains that economic downturns may be exacerbated and prolonged if major austerity is introduced at the low point of recessions. Some European nations appear to validate that theory today. Indeed, several studies find that consolidation is generally initiated when economic troubles descend. One study finds that the likelihood of fiscal consolidation increases with the rate of unemployment. ${ }^{40}$ Another finds that more successful consolidations began with weak economic activity. ${ }^{41}$

Simply put, the politics and economics of fiscal austerity may indeed clash, with nations doomed to undertake pro-cyclical fiscal policy during the troughs of the business cycle. In the short-term, it may very well be easier for leaders to gain support for consolidation when the economy appears to be flat-lined and even in crisis.

May 1990. Little progress was made until late June when President Bush and House Speaker Foley agreed to put tax increases and entitlement reforms on the table.").

38. See U.S. Gov'T ACCOUNTABILITY OFFICE, GAO/AIMD-95-30, DEFICIT REDUCTION: EXPERIENCES OF OTHER NATIONS 72 (1994); U.S. GOV'T ACCOUNTABILITY OFFICE, supra note 32 , at 130 .

39. See U.S. Gov'T ACCOUNTABILITY OFFICE, supra note 32, at 23.

40. Larch \& Turrini, supra note 29 , at 11.

41. See Guichard et al., supra note 23 , at 15. 
Fortunately, the relationship between austerity and growth is not so simple. Even the most shortsighted leader might realize that undertaking austerity in the depths of recessions is not only the wrong economic medicine, but is also bad politics. As many European nations are finding today, cuts only accentuate short-term economic woes and hasten the firing of national leaders in the process. ${ }^{42}$

Some studies are more sanguine about the economic timing of consolidation. One study finds that governments are more likely to undertake consolidations in good economic periods. ${ }^{43}$ Another study finds that the fallout from economic crises might hinder retrenchment. ${ }^{4}$ A study of the largest consolidation also finds that growth rates picked up before fiscal tightening began, ${ }^{45}$ as shown in Figure 4 excerpted from that study. The figure shows that economic growth rates started to climb from their lowest point-Year $0-$ a year before the initiation of fiscal consolidation programs.

42. Alesina has long noted that fiscal austerity is in fact compatible with economic restoration as long as it is done on the spending side. Expansionary contractions can occur when cuts are perceived as permanent and change their savings behavior and their expectations of interest rates. Alberto Alesina \& Silvia Ardagna, Tales of Fiscal Adjustments, 13 ECON. POL'Y 489, 491-98 (1998).

43. See Jürgen von Hagen \& Rolf R. Strauch, Fiscal Consolidations: Quality, Economic Conditions, and Success, 109 PUB. CHOICE 327, 343 (2001).

44. See Salvador Barrios et al., EU Fiscal Consolidation After the Financial Crisis, in EUROPEAN COMMISSION ECONOMIC PAPERS 418, at 9-11 (2010).

45. Blöchliger et al., supra note 24 , at 12 . 


\section{Figure 4: Economic growth rates and consolidation (consolidation begins in year 0 ) \\ Panel A. Growth rates}

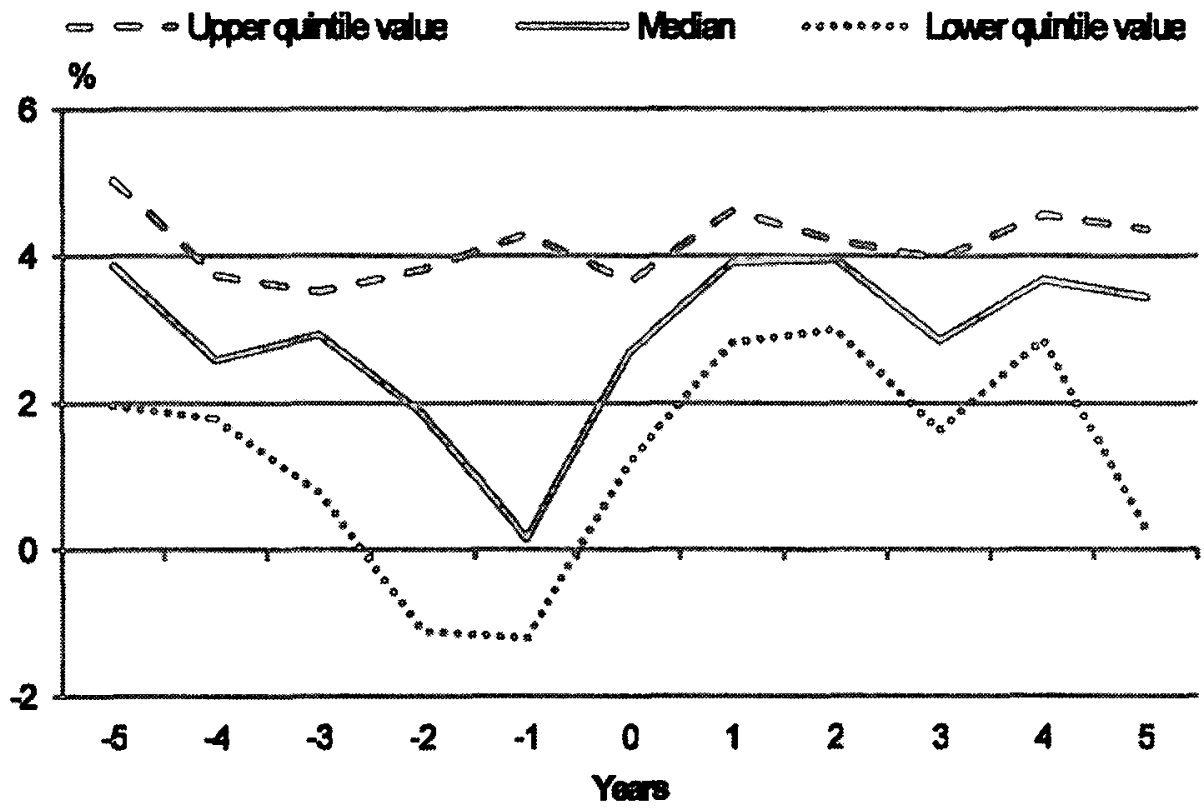

Source: Hansjörg Blöchliger et al., Fiscal Consolidation: Part 4. Case Studies of Large Fiscal Consolidation Episodes 12 (Org. for Econ. Co-Operation \& Dev., Econ. Dep't, Working Paper No. 935, 2012), available at http://dx.doi.org/10.1787/5k9fdf5xptlq-en.

This finding contradicts the economic crisis hypothesis by suggesting that nations wait until economies start to recover to initiate austerity measures.

Whether by forethought or fortuitous accident, leaders in some nations seem to have the uncanny ability to initiate austerity during what this article will call a "goldilocks economy"-an economy that is not too good, but not too bad. In these times, deficit reduction can boost growth, partly by convincing central banks and markets to lower interest rates. ${ }^{46}$

Among our case-study nations, Sweden undertook significant deficit reduction in 1994 just as its economy was beginning to restore growth from its recession lows. Well-timed fiscal consolidation can aid a healing economy by instilling confidence in global markets and central banks;

46. Von Hagen \& Strauch, supra note 43 , at 333-336. 
indeed, the interest rates on the ten-year government bond dropped from 10 percent to 5 percent between 1994 and $1998 .{ }^{47}$ For the OECD as a whole, half of the eighty-five consolidations from 1978 through 2007 were sustained long enough to stabilize the debt-to-GDP ratio for at least two years. ${ }^{48}$

Importantly, well-timed consolidations also offer political bonuses. Governments undertaking painful cuts and tax increases can point to tangible progress in economic growth to justify the programmatic and fiscal sacrifices. President Bill Clinton was able to do this in the aftermath of passing the 1993 deficit reduction legislation, as a growing economy gained new momentum on the way to a growth boom that lifted all fiscal boats. ${ }^{49}$ His predecessor, President George H.W. Bush was not so lucky. He was fated to begin the U.S. consolidation in 1990 during a worsening economy and never really was able to point to progress in the remaining two years of his term. In fact, notwithstanding substantial cuts and tax increases, deficits worsened in the first several years due to weaker than expected growth, depriving him of the ability to brag about the fiscal progress he helped institute. $\mathrm{He}$ lost the election of 1992 to Mr. Clinton, enabling Clinton to claim credit for the progress that was kicked off during Bush's tenure. ${ }^{50}$

While waiting for economic growth to resume before undertaking consolidation might be appropriate for some nations, many do not have this luxury. Nations that must finance their debt may ultimately be priced out of the market if they fail to generate confidence in their economic and fiscal management. Moreover, waiting too long may undercut the sense of urgency that is often critical to inspire support for fiscal sacrifice.

Indeed, Schick argues that in a financial crisis, fiscal policy may need to follow a different compass than that prescribed by the textbooks. In normal recessions, governments should run a deficit by stimulating demand. In this Great Recession, however, it is critical for each government to promote confidence using its markets. This means that bond and credit markets become more critical to sustainable financing for government. And this means that austerity will have to take a front, not a back, seat. ${ }^{51}$ Thus, competitive capital markets may serve to place

47. See ANDREW Lilico et Al., Controlling Spending AND Government Deficits 9 (2009).

48. See Guichard et al., supra note 23 , at 10.

49. See IwAN Morgan, The Age of Deficits: PREsidents ANd Unbalanced Budgets FROM JIMMY CARTER TO GEORGE W. BUSH 175 (2009).

50. See id. at 149-157.

51. ALLEN SCHICK, ORG. FOR ECON. CO-OPERATION \& DEV., LESSONS FROM THE CRISIS: WILL THE CRISIS CHANGE BUDGETING? 9-10 (2012). 
a limit on the ability of many nations to sustain expansionary fiscal policies during periods of recession.

Several of the five case study nations felt compelled to attack deficits during the depths of recessions. In New Zealand in 1984, an impending economic crisis marked by heavy capital outflows precipitated large exchange rate devaluation, a credit downgrade, high inflation, and high debt. In response, the government implemented a series of sweeping economic reforms to reduce the role of government in the economy and win back the confidence of global markets. This included reducing a deficit of 6.5 percent of GDP by increasing taxes and cutting expenditures. Given the depth of the recession, unemployment grew and it took nearly seven years of reform just to raise GDP 2.8 percent higher than it was at the outset of the crisis. ${ }^{52}$

Nations undertaking sustained consolidations reaped significant economic benefits over time. All five of our nations realized major improvements in interest rates, economic growth, and decreased public debt. Sustained surpluses enabled these nations to survive the Great Recession with far greater resilience, with less crippling deficits and debt than others. As shown in Figure 5, the surplus group of nations lapsed into deficits averaging 2.8 percent of GDP by 2010, compared with 4.8 percent for OECD as a whole and 9.2 percent for the nations with chronic deficits during the past ten years.

52. U.S. Gov'T ACCOUNTABILITY OFFICE, supra note 38, at 130-39. 
Figure 5: Deficit/surplus as a percentage of GDP (2000-2010)

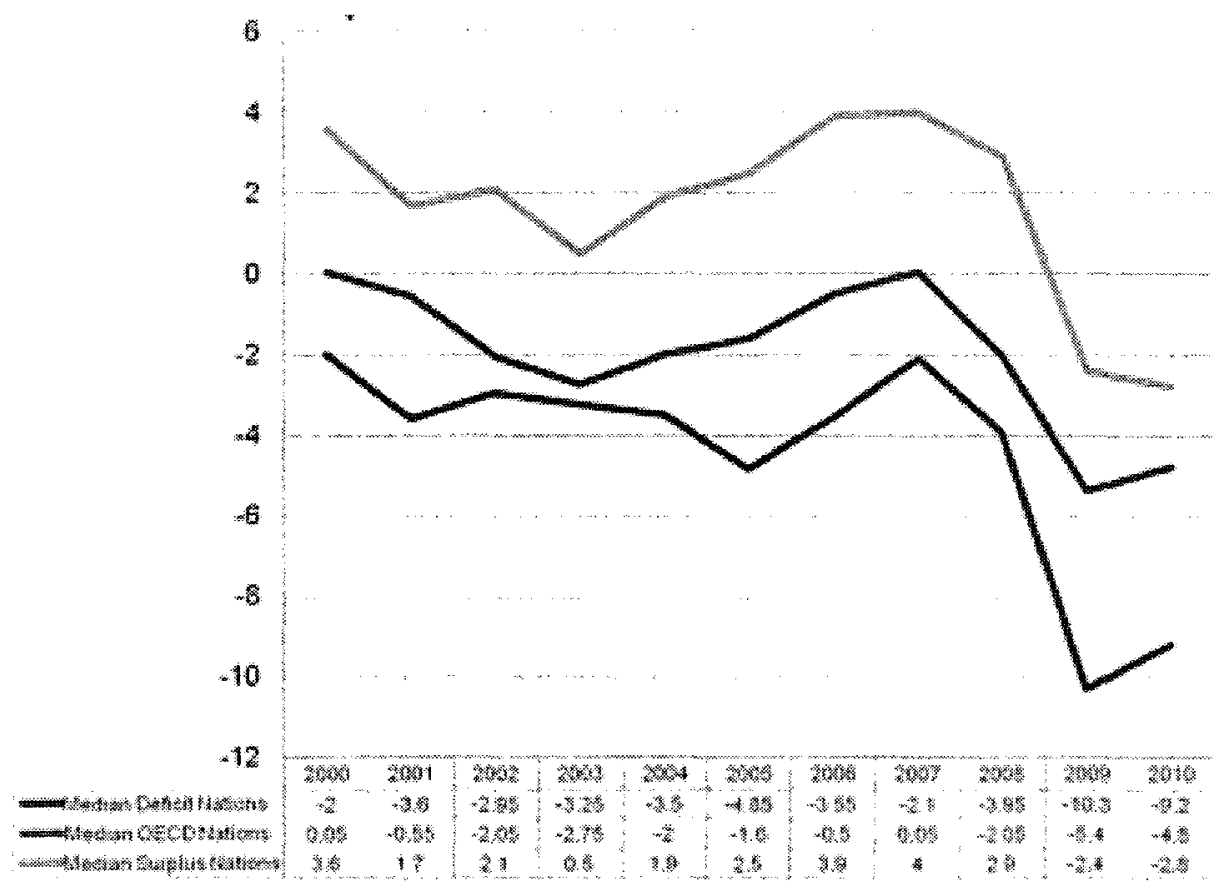

Source: Paul Posner \& Matthew Sommerfeld, The Politics of Fiscal Austerity: Democracies and Hard Choices 18 (Org. for Econ. Co-Operation \& Dev., Governance and Territorial Dev. Directorate 2012), available at $\mathrm{http}: / / \mathrm{www} .0 e c d . o r g / o f f i c i a l d o c u m e n t s /$ publicdisplay documentpdf/?cote=GOV/PGC/SBO $\% 282012 \% 294 \&$ doclanguage $=e n$.

\section{The PIVOtal Role of Political Institutions}

Political institutions are critical in determining whether and how fiscal consolidations will be shaped to respond to economic and fiscal triggers. Given the high stakes involved, a government must have sufficient political support to form an alliance with key groups and publics to push for needed reforms and retrenchment.

Among the political variables associated with consolidation, two stand out: the timing of consolidation and the relative strength of the ruling party. With regard to timing, there is strong evidence that governments are most successful when consolidations are introduced in the immediate aftermath of an election. New governments have high 
standing with publics and are relatively untarnished by the slings and arrows of governing. 53

This effect is amplified when the incoming government campaigned on fiscal consolidation issues. In these cases, the party can claim a mandate to impose consolidation from the campaign itself. Successful consolidations are not introduced by stealth but rather with broad publicity to capitalize on momentum drawn from the election. Fully transparent and compelling public rationales are the touchstone for the legitimacy of consolidations, and governments that fail to capitalize on positive public sentiment lose the political high ground of legitimacy that is so desperately prized in such a high stakes political contest.

Among our five case studies, the newly elected governments of Sweden and Canada both ran on the need for consolidation, enabling them to claim a mandate for strong action. On the other hand, in the United States, President George H.W. Bush stressed tax cuts rather than consolidation in the 1988 election. ${ }^{54}$ This complicated and undermined his ability to promote his deficit reduction agreement with Congress that included tax increases, particularly within his own Republican party, which never forgave him for abandoning what was perceived as a central pledge in return for giving him the party's nomination.

The research here suggests that, as important as political variables are, research is often divided about their influence on fiscal consolidation. ${ }^{55}$ For instance, the findings are conflicted with regard to the impact of strong ruling parties on the prospects for fiscal consolidation. Some studies find that single-party governments are more effective in forging agreements than coalitions; strong majorities are associated with more decisive actions and more dramatic "cold showers."56 Strong parliamentary majorities are more likely to fashion lasting fiscal corrections and more fundamental reforms of major spending policies. Alesina finds that fiscal stabilization is facilitated by presidential systems with unified parties controlling the legislative branch. 57

However, other research suggests that strong single-party governments do not have statistically significant effects on deficit

53. See Guichard et al., supra note 23 , at 21 .

54. See MoRgan, supra note 49 , at 124 .

55. See Kickert et al., supra note 26 , at 19.

56. See Larch \& Turrini, supra note 29 , at 15.

57. Alberto Alesina, Silvia Ardagna \& Francesco Trebbi, Who Adjusts and When? On the Political Economy of Reforms 2-3 (Nat'l Bureau of Econ. Research Working Paper Series, Working Paper No. 12049, 2006). 
reduction.58 Countries with minority governments and coalition governments do as well as single-party majorities. One leading scholar even suggests that single-party majorities in parliamentary systems may be less likely to take on difficult policy choices than coalition or minority governments because of the singular concentration of blame on that one party. By contrast, divided governments facilitate hard choices by spreading blame to all parties and interests, assuming they can reach an agreement among themselves-a heroic proposition in some systems. ${ }^{59}$

Similar disagreements have broken out over the relative efficacy of presidential versus parliamentary governments in dealing with fiscal sacrifice and other hard choices. On the one hand, presidential systems may be at a disadvantage. Because the president and the legislature are institutionally and electorally independent, the president faces a more independent legislature, even under unified government when the same party controls both institutions. Strong parties can bridge the institutional differences, but at the same time, they can make agreement under divided government doubly difficult.

However, presidential systems have several advantages. When coalitions govern, the coalition partners in parliament have greater potential leverage because they can credibly threaten to remove the government through a vote of no confidence-an option not available under a presidential separation of powers system. Also, according to Cheibub, presidents are under greater pressure from publics to achieve deficit reduction than parliamentary leaders, owing to their greater visibility and responsibility for fiscal outcomes. ${ }^{60} \mathrm{In}$ fact, Cheibub finds that presidential systems do a better job of fiscal management and budgetary control than parliamentary systems. 61

Interestingly, political orientation does not seem to matter. Molnar suggests that centrist parties are most likely to reduce debt, but Alesina and Perotti find that centrist governments are less likely to mount successful consolidations. ${ }^{62}$ In several of our case study nations, ruling

58. See Takayuki Sakamoto, Effects of Government Characteristics on Fiscal Deficits in 18 OECD Countries, 1961-1994, 34 ComP. PoL. STUD. 527, 542-43 (2001); Uwe Wagschal \& Georg Wenzelburger, The Pre-Crisis Perspective: When Do Governments Consolidate? 19 (Mar. 24, 2011) (unpublished paper), available at https://www.wipo.uni-freiburg.de/ dateien/tagungen/FiscalConsolidation2011/fiscalsubmissions/Wagschal.

59. See Paul Pierson, Dismantling the Welfare State? Reagan, Thatcher and THE POLITICS OF RETRENCHMENT 33-34 (1994).

60. See José Antonio Cheibub, Presidentialism, Electoral Identifiability, and Budget Balances in Democratic Systems, 100 AM. PoL. SCI. REV. 353, 365 (2006).

61. $I d$.

62. See Alesina \& Perotti, supra note 31 , at 21 . 
parties were effective in preempting the positions of opposing parties. In nations like Australia and New Zealand, left wing parties became credible reformers when they championed reforms to pensions and other programs supported by their base in the name of economic growth. Whether pursued by left or right wing parties, such a strategy can be very effective in disarming the opposition and capturing the broad center of the political spectrum, albeit at some risk of alienating their base. The presidency of George H.W. Bush illustrated this latter risk when his support for tax increases in 1990 weakened support from conservatives in the Republican Party. In turn, this jeopardized the prospects of Congressional approval for deficit reduction and may have, ultimately, led to his defeat in the 1992 elections.

In our five case studies, patterns of political party control spanned the entire range of possible models for political support as indicated in Table 6. Canada is the best pure example of a partisan model with a single ruling party controlling government from 1993 through 2006.

Table 6: Partisan models for fiscal consolidation

\begin{tabular}{|c|c|c|c|}
\hline & Partisan & Cross-partisan & Copartisan \\
\hline Australia & $\mathrm{x}$ & $\mathrm{x}$ & $\mathrm{x}$ \\
\hline Canada & $\mathrm{x}$ & & $\mathrm{x}$ \\
\hline New Zealand & & $\mathrm{x}$ & $\mathrm{x}$ \\
\hline Sweden & & $\mathrm{x}$ & \\
\hline United States & $\mathrm{x}$ & & \\
\hline
\end{tabular}

Source: Author's findings derived from alignment at the time that deficit reduction began in each nation.

The other cases illustrated a cross-partisan coalition where several parties joined in with a major party to govern. This was the case in Sweden in 1994 when the Social Democratic Party, even while heading a coalition, gained approval for major consolidation initiatives that not only rapidly improved the fiscal balance but also succeeded in reforming the nation's pension system. The United States veered from the 1990 consolidation under a cross-partisan coalition to a purely partisan consolidation in 1993, then back to a cross-partisan coalition in 1997.63

Table 6 also suggests that several nations exhibited copartisanship, meaning that both parties essentially took turns implementing fiscal consolidation, notwithstanding some modest variations. In New Zealand, the different party coalitions all pledged fealty to the same

63. See Allen Schick, The Federal Budget: Politics, Policy, Process 24-27 (3d ed. 2007). 
fiscal goal of reducing debt to a set percentage of GDP, albeit with differing relative agendas and mixes of spending and revenues to achieve these targets. ${ }^{64}$

There are times when national leaders succeed in gaining genuine bipartisan support for major reforms. This was particularly the case with pension reforms. Given the political resistance to change in programs and structural policies, governments had incentives to reach out beyond their coalitions to form bipartisan or all-party commissions and task forces, as shown in Table 7.65

Table 7: Multi-party vehicles in pension reform

Canada-reform of the Canada Pension Plan was adopted after two-thirds of the provinces adopted the arrangement.

Spain - the 1996 Toledo Pact is an all-party agreement ratified by unions and employer associations to reform the Spanish old age security system.

Sweden - the 1998 reform of pensions was developed through an all-party agreement resulting in a new system providing incentives to prolong work and create notional private accounts.

Switzerland and New Zealand-both held referenda on major pension reforms in 1995 and 1997.

Austria-1997 reform was a product of government bargaining with unions.

United States-1983 reform was the product of a commission with participation by leaders of both parties, which developed a consensual social security reform including extension of retirement age and increased payroll taxes.

64. See U.S. Gov't ACCOUNTABILITY OFFICE, supra note 32, at 130-149.

65. John Myles \& Paul Pierson, The Comparative Political Economy of Pension Reform, in The New Politics of the Welfare State 305, 322-23 (Paul Pierson ed., 2001). 


\section{THE NATURE AND COMPOSITION OF CUTS}

\section{A. Types of Consolidation Strategies}

The economic success and political sustainability of fiscal consolidation is shaped by the kinds of consolidation strategies adopted. On the economic front, considerable research has long supported the conclusion that successful consolidations are expenditure based. ${ }^{66}$ One study found that expenditure cuts contribute 52 percent of successful consolidations compared to only 12 percent for unsuccessful ones. 67 Spending consolidations are more likely to stabilize debt. Economists generally agree that spending cuts have less immediate impact on economic growth than tax increases. ${ }^{68}$ Moreover, spending cuts, particularly reforms to politically entrenched programs, may signal to bond markets and savers alike the government's resolve to reduce deficits and debt over the long term. 69

These general conclusions all depend on the timing and nature of tax increases and spending cuts. Recent studies suggest that revenuebased consolidations can also be effective, particularly in low-tax nations. ${ }^{70}$ Spain had revenue consolidations that were helpful. While revenue increases may be particularly counterproductive in weak economies, their impacts on stronger economies may be more salutary. Revenue-based consolidations can also be effective if tax increases are concentrated in more indirect taxes like consumption and excise taxes, which have less growth-dampening effects than increased taxes on income and investment. ${ }^{71}$

Regardless of the economic efficiency implications, political concerns prompted some nations to package tax increases with spending cuts. In a nation like the United States, the failure to include both tax increases and spending cuts would likely have doomed any chance of crosspartisan collaboration.

The specific types of spending cuts will also affect the economic impact of consolidations. Transfers appear to be most associated with success; however, wage cuts are also important. Structural reforms in unemployment and labor protections also appear to have lasting effects

66. Alesina \& Perotti, supra note 31 , at 18.

67. Von Hagen \& Strauch, supra note 43 , at 330.

68. See Guichard et al., supra note 23, at 16.

69. See id. at 16 ("The longer an episode lasted the higher was the probability that it would achieve success.").

70. See Larch \& Turrini, supra note 29 , at 22.

71. See George C. Tsibouris et al., Int'l Monetary Fund, Experience with Large Fiscal Adjustment, Occasional Paper No. 246, at 10-12 (June 14, 2006). 
on consolidation. Cuts in investment, on the other hand, may reduce growth and are often subject to reversal. For large consolidations, cuts in investment were more significant than wages. Investment halved during consolidation episodes. ${ }^{72}$

For all consolidations, revenue increases counted for a larger faction of total reductions. ${ }^{73}$ Two-thirds of episodes had larger revenue increases than spending. ${ }^{74}$ But for the largest consolidations, revenues contributed only a third. ${ }^{75}$ One study suggests that the spending cut factor has recently weakened, and a mix of revenue and spending have become more important. This might be because earlier consolidations already harvested the low-hanging fruit on spending. Further, the highest spending nations may have converged to the median, removing their incentive to dig deeper for spending cuts. ${ }^{76}$

Beyond the mix of revenue and spending, the size and pace of consolidations have economic and political implications as well. Generally, incremental or decremental cuts and tax increases have been viewed as most politically acceptable. 77 Tempering the magnitude of cuts can also mitigate potential opposition. Kickert's latest research on the cutbacks in Europe following the most recent financial crisis suggests that most cutback decisions were moderate and iterative. The sheer size of the fiscal gaps, however, required governments to undertake an escalating series of cuts when initial incremental decisions were not sufficient. ${ }^{78}$

While engendering less political support, "cold shower" and large consolidations appear to be more successful in resolving fiscal deficits than gradual and more modest initiatives. Table 8 below shows that most European nations undergoing consolidations undertake cold showers rather than a gradual approach. Needless to say, those nations engaging in cold shower consolidations are prompted by economic crisis and strong political majorities.

The strength of cold shower initiatives is their promise of greater economic and political returns more quickly. For one thing, it sends a more definitive signal to markets about the seriousness of the proposed consolidation. Cold showers may also be more comprehensive, opening up opportunities to spread the pain across major programs and

72. Blöchliger et al., supra note 24 , at 10 .

73. See Guichard et al., supra note 23 , at 10.

74. Id.

75. Pete Devries et al., A New Action-Based Dataset of Fiscal Consolidation 82 (Int'l Monetary Fund, Working Paper No. 11/128, 2011).

76. See Larch \& Turrini, supra note 29 , at 21.

77. See Aaron B. Wildavsky, The Politics of the Budgetary Process 13 (1964).

78. See Kickert et al., supra note 26 , at 20. 
constituencies-and possibly to engage in compensatory side payments as will be discussed below. Large consolidations tend to use a broader mix of spending and tax increases to achieve their daunting fiscal targets. ${ }^{79}$

The disadvantages are that cold showers must generate savings immediately to achieve their bold fiscal goals. As a result, cold showers tend to disproportionately cut programs like investments with more immediate consequences for deficit reduction, regardless of their longerterm consequences for the economy. Moreover, cold showers make it difficult to undertake reforms to sensitive pension and even health care programs-reforms which ideally call for longer lead times and phase ins to help clients adjust their life plans to new fiscal realities. ${ }^{80}$

Table 8: Cold shower consolidations vs. gradual consolidations

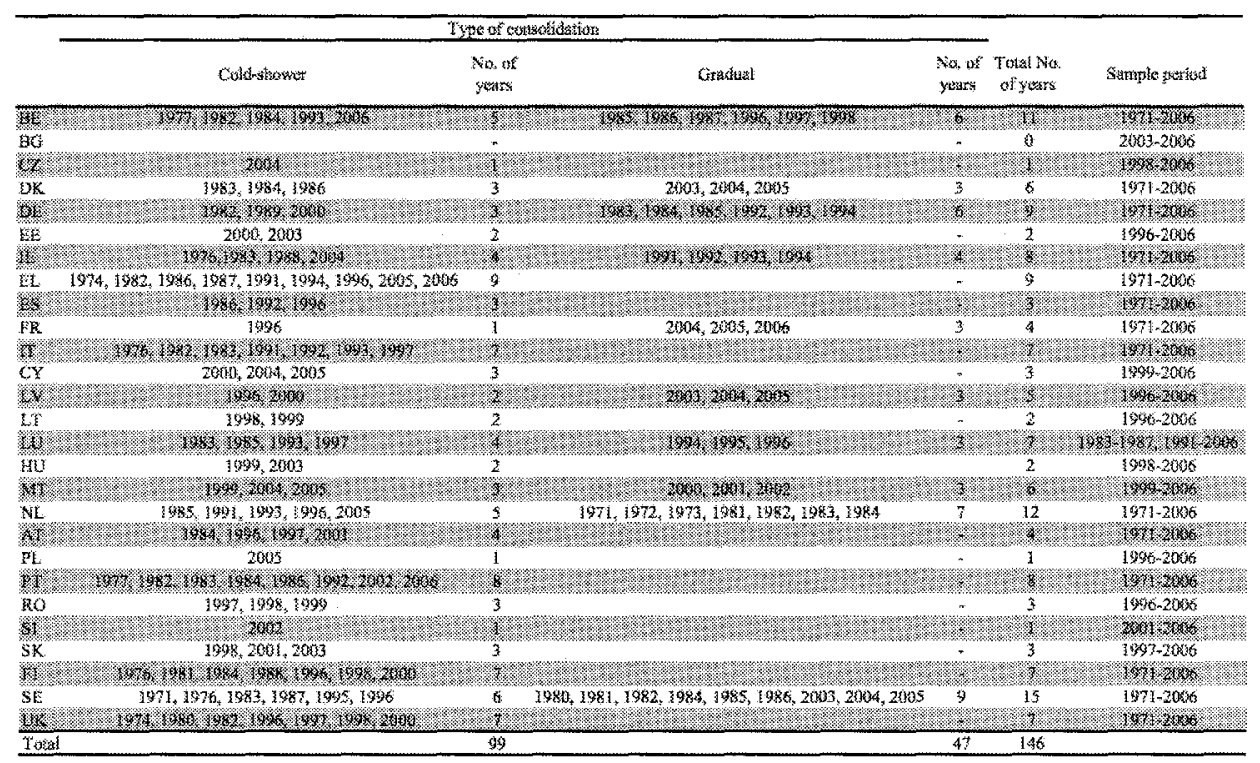

Source: Martin Larch \& Alessandro Turrini, Received Wisdom and Beyond: Lessons from Fiscal Consolidations in the EU, in EUROPEAN COMMISSION ECONOMIC PAPERS 320, at 8 (2008).

79. Molnar, supra note 28 , at 22 .

80. Larch \& Turrini, supra note 29 , at 15. 


\section{B. Dissipating Political Tensions Created by Consolidations}

Leaders have to be mindful about the political tensions that consolidation can bring when developing packages and priorities. While spending cuts may have greater effects on credit market credibility, they can also have disproportionate effects on inequality when compared to tax increases. Leaders must cover their political risks by pursuing strategies that spread the sacrifice and help obfuscate blame for imposing painful decisions.

Our case study nations used a number of strategies to facilitate the imposition of losses that have been observed to be common in advanced political systems. ${ }^{81}$ These strategies included the following:

- Apportioning sacrifice in an equitable manner through strategies such as across-the-board cuts, balancing spending, and revenue actions. Such strategies help promote a perception of fairness. They also intercept prisoners' dilemmas by ensuring groups that their political competitors who might dodge the deficit bullet will not exploit their sacrifices. For instance, Sweden imposed an 11 percent across-the-board cut on nearly all programs and agencies at the outset of their consolidation in $1994 .{ }^{82}$

- Compensating losers with packages that cement coalitions by providing gains to offset a portion of the losses of major groups: One example of this strategy is tax reform where reductions in tax expenditures from eliminating breaks such as mortgage interest deductions were partially offset by dramatic cuts in tax rates in several of our case study nations. In the United States, major consolidations in 1990 and 1993 were coupled with significant expansions of the Earned Income Tax Credit for low-income families and individuals and increased eligibility for Medicaid health coverage for low-income groups. ${ }^{83}$ In some nations the desire to

81. See generally PIERSON, supra note 59.

82. U.S. Gov'T ACCOUNTABILITY OFFICE, supra note 38, at 164.

83. See Sophie Feldman \& Melissa Boteach, Timeline: Cutting Poverty and the Federal Deficit Is Possible, CTR. FOR AM. Progress (Aug. 15, 2012), https:/www.american 
compensate consolidation's losers can occur sequentially as nations wait for surpluses to provide tax cuts and new spending initiatives for publics suffering from "consolidation fatigue." While such initiatives ultimately dissipated surpluses in the United States, other case study nations like Canada, New Zealand, and Australia were able to provide these benefits without losing their surpluses. ${ }^{84}$

- Phasing in cuts by making wedge shaped cuts that grow over time: The political impacts of spending cuts and tax increases can be substantially blunted if they are introduced slowly over a number of years to provide ample time for transition and adaptation. For instance, pension reforms often phase in increases in the age requirement for full benefits over several decades to provide time for those affected to adjust their career and savings plans.

- Promoting larger, more sweeping changes that can yield more demonstrable fiscal progress: Ironically, sweeping changes are positively related to political success. Large packages not only improve chances for dramatic gains in economic outcomes, but also help promote perceptions of fairness by spreading the pain across more stakeholders. A former high Swedish finance official writes that a broader package of changes helps offset distributional effects, particularly if both spending cuts and tax increases are included. ${ }^{85}$ OECD research suggests that large multiyear adjustments can

progress.org/issues/poverty/news/2012/08/15/12021/timeline-cutting-poverty-and-thefederal-deficit-is-possible/.

84. See U.S. GOV'T ACCOUNTABILITY OFFICE, supra note 38 , at 74 ("[T]hese countries have taken steps to use surpluses to address long-term national priorities, they have also allowed for a portion of their surpluses to be used for more immediate needs.").

85. Jens Henriksson, TEN Lessons About Budget Consolidation 18-19 (Jean Pisani-Ferry ed., 2007). 
make reforms possible that would not have been able to find support on their own. ${ }^{86}$

Many of these strategies help democratic leaders protect themselves against the political risks associated with fiscal consolidation. Douglas Arnold stresses the importance of designing policies to obfuscate or share blame. ${ }^{87}$ Hiding painful choices in larger omnibus legislation can buffer the traceability chain and enable legislators to avoid taking politically difficult votes. Delegating hard choices to independent bodies such as commissions or executive agencies is another time-honored strategy to spread and avoid blame.

\section{FISCAL RULES}

During times of fiscal austerity, formal rules and structures become more essential for budgeting as the stakes involved with budget decisions grow. In Europe, for instance, the financial crisis and rapid deterioration of the fiscal position of the European countries led the European Union to introduce reforms to strengthen enforcement of existing fiscal rules through a new Fiscal Compact, which came about in January 2013. This featured more stringent fiscal balance requirements, greater centralization of rule making, stronger and more binding budget frameworks, and harsher penalties. ${ }^{88}$ Fiscal rules can serve as a useful supplement to coalitions, replacing folkways and even moral consensus that used to form the parameters and glue that sustained a responsible center for budgeting. A recent IMF study shows that eighty nations have fiscal rules, compared to only seven in 1990 . Most have a combination of rules. 89

Ideally, fiscal rules and institutions can provide additional fiscal discipline. The rationale is to force all players to internalize the fiscal effects of their actions. Thus, if a fiscal rule succeeds in forcing advocates to "pay for" new spending or tax cuts, this in itself could prevent the unlimited grazing of the fiscal commons by interests who would otherwise enjoy concentrated benefits.

Fiscal rules can include any of the following: a goal or target for deficits or debt over time, a set of processes for negotiating the budget including constraints on fiscal expansions, a set of institutional roles for

86. ORg. For Econ. Co-Operation and Dev., Restoring Fiscal Sustainability 8 (2010), available at http://www.oecd.org/governance/budgeting/44473800.pdf.

87. DOUGLAS R. ARNOLD, LOGIC OF CONGRESSIONAL ACTION 8 (1992).

88. Int'l Monetary Fund, supra note 2, at 12.

89. See Int'l Monetary Fund, Fiscal Rules-Anchoring Expectations for Sustainable Public Finances, at 7-9 (Dec. 16, 2009). 
budgetary actors designed to empower guardians over claimants, and information promoting transparency and accountability for budgetary outcomes. ${ }^{90}$ In many cases, fiscal rules and institutions have the goal of limiting the choices of democratic leaders, tying their hands to the proverbial mast to save them and their nations from their own hyperresponsive tendencies. ${ }^{91}$ Whether it be delegating choices to a commission or providing for automatic formulas that trigger fiscal actions on cue from certain indicators, the not-so-hidden agenda of many fiscal rules is to compensate for what are perceived to be the fiscal ambivalence of democratic leaders. ${ }^{92}$

Research on fiscal consolidations is mixed, but most studies show that the coverage and strength of fiscal rules helps promote consolidation. One study suggests that balanced budget rules are more important than expenditure rules. ${ }^{93}$ Another study suggests that budget balance requirements enable a more balanced focus on both revenues and spending. ${ }^{94}$ Yet, other studies find that balanced budget requirements can produce pro-cyclical decisions and be evaded by classifying various activities as off budget. 95

In our case study nations, fiscal rules were instrumental in enforcing political agreements for consolidation. Canada threatened agencies with a 10 percent across-the-board cut if the government's proposals for spending cuts from program review were thwarted. ${ }^{96}$ Spending ceilings in Sweden helped the parliament take ownership of fiscal consolidation and kept the entire framework on track. Surplus and debt targets in Sweden and New Zealand garnered sufficient agreement across all political parties to inspire continued retrenchment where necessary. ${ }^{97}$ In the United States, both spending caps and pay-as-

90. Id. at 5-12.

91. Jürgen von Hagen, European Experiences with Fiscal Rules and Institutions, in FisCAL CHALLENGES: AN INTERdISCIPLINARY APPROACH TO BUdGET POLICY 117 (Elizabeth Garrett et al. eds., 2008).

92. Id. at 116 .

93. Xavier Debrun, Laurent Moulin, Alessandro Turrini, Joaquim Ayuso-i-Casals \& Manmohan S. Kumar, Tied to the Mast? National Fiscal Rules in the European Union, 23 ECON. POL'Y 298, 342 (2008).

94. See generally Larch \& Turrini, supra note 29, at 12 (suggesting that budget balance rules that focus only on expenditures have less significant budgetary impacts).

95. Barry Anderson \& Joseph J. Minarik, Design Choices for Fiscal Policy Rules, 5 OECD J. ON BUDGETING 159, 190 (2006).

96. Paul Posner \& Matthew Sommerfeld, The Politics of Fiscal Austerity: Democracies and Hard Choices 25 (Org. for Econ. Co-Operation \& Dev., Governance and Territorial Dev. Directorate 2012), available at http://www.oecd.org/officialdocuments/publicdisplay documentpdf/?cote=GOV/PGC/SBO $\% 282012 \% 294 \&$ doclanguage=en .

97. See U.S. Gov'T ACCOUNTABILITY OFFICE, supra note 32, at 11 ("The countries . . studied have generally reached consensus on how they plan to use surpluses . . . As part 
you-go (PAYGO) requirements for new legislation enabled national leaders of both parties to sustain fiscal consolidation for nearly ten years. ${ }^{98}$

Still, it is important to place fiscal rules in perspective. Much as proponents of such rules desire them to be self-executing, the effectiveness of rules will ultimately still depend on their alignment and support with political values and leaders. Wildavsky identified the issue best-if the budget process is to be changed then one must alter the underlying political system as well. ${ }^{99}$ Irene Rubin reminds us that "budget reform can help carry out goals of politicians once they have made up their minds, but it cannot make up their minds." 100 As Roy Meyers has asserted, budget rules are endogenous to the political system that created them, which constitutes both a strength and a weakness. ${ }^{101}$

Fiscal rules in democratic systems have an independent effect more as a reinforcement to the substantive fiscal policy commitments made by political regimes than as a catalyst for forcing agreement on discipline and goals. Hallerberg's work shows that fiscal rules are most appropriate for coalitions where each party is bound to the overall political regime through contractual commitments. Nevertheless, such rules become superfluous and often ignored in strong single party regimes that can rely on a hegemonic direction by the government leaders. ${ }^{102}$ Similarly, in the United States, fiscal rules are useful to bind a coalition to a set of policy goals already agreed to through political bargaining, but the rules become irrelevant when the political regime changes. Thus, for instance, the PAYGO and spending caps agreed to in

of their strategies, they have developed explicit goals to guide fiscal policy and have justified their goals with compelling rationales that often pointed out the potential fiscal and economic benefits of continued fiscal discipline .... New Zealand and Sweden have focused on the need to reduce debt as a justification for sustained surpluses.").

98. PAYGO, or pay-as-you-go, "is a budget rule requiring that, relative to current law, any tax cuts or entitlement and other mandatory spending increases must be paid for by a tax increase or a cut in mandatory spending." Rudy Penner, Budget Process: What is PAYGO?, in The TAX POLICY BRIEFING BOOK: A CitIzens' GuIde FOR THE 2012 ELECTION AND BEYOND (Urban-Brookings Tax Policy Center, 2011), available at http://www.tax policycenter.org/briefing-book/TPC_briefingbook_full.pdf

99. Aaron Wildavsky, Political Implications of Budgetary Reform, 21 PUB. ADMIN. REV. 183,185 (1961).

100. Irene S. Rubin, Budget Theory and Budget Practice: How Good the Fit?, 50 PUB. ADMIN. REV. 179, 184 (1990).

101. Roy T. Meyers, The "Ball of Confusion" in Federal Budgeting: A Shadow Agenda for Deliberative Reform of the Budget Process, 69 PUB. ADMIN. REV. 211, 214 (2009).

102. MARK HALlerberg, Chapter 9 Conclusion: Application of the Fiscal Governance Approach in Europe and Beyond, in DOMESTIC BUDGETS IN A UNITED EUROPE: FISCAL GOVERNANCE FROM THE END OF BRETTON WOODS TO EMU 218 (2006). 
1990 were sustained until 2002. ${ }^{103}$ Yet, these same rules became superfluous and were disregarded when President George W. Bush inherited a budget surplus and was able to work exclusively with a Republican-controlled Congress without Democratic Party assistance. ${ }^{104}$

The recent IMF study on fiscal rules worldwide reflected findings similar to the U.S. example. In the conclusions, the IMF observes that political institutions, public opinion, and leadership fundamentally influence fiscal progress, with rules playing a supplemental and important role. Many nations adopted rules several years after fiscal consolidation began to solidify and institutionalize political agreements. ${ }^{105}$

\section{The Political Outcomes OF AUSTERITY}

When nations in fact construct and implement credible plans to reduce spending and increase revenues, the conventional view would conclude that political leaders have only enacted these measures as a last resort. And most assuredly, having undertaken a politically unnatural act, those government leaders would surely not survive politically for very long after their courageous actions.

Conventional wisdom aside, intriguing studies suggest that not only have national leaders taken the initiative to pilot consolidation through the political straits, but they were rewarded electorally as well. Brender and Drazen's study used data from twenty-three OECD nations from 1960 through 2003 on 164 elections. ${ }^{106}$ They found that governments achieving lower deficits through policy actions actually increased the probability of their reelection. ${ }^{107}$ Controlling for changes in the economy, a reduction of one percentage point in the deficit-to-GDP ratio increased the probability of reelection for existing regimes by 5.7 percentage points. ${ }^{108}$ The authors attribute this surprising finding to the fact that voters do not like deficits because they perceive that deficits will entail future tax increases or spending cuts in subsequent years. ${ }^{109}$

A 1998 study by Alesina, Perotti, and Tavares echoed similar findings. When examining whether governments following tight fiscal

103. Allen Schick, The federal Budget: Politics, Policy and Process 58 (3rd ed. 2007).

104. Paul L. Posner, Budget Process Reform: Waiting for Godot, 69 PUB. ADMIN. Rev. 233,240 (2009).

105. Int'l Monetary Fund, supra note 89, at 19.

106. Adi Brender \& Allan Drazen, Political Implications of Fiscal Performance in OECD Countries, FISCAL INDICATORS 960 (2007).

107. Id. at 964.

108. Id.

109. Id. at 966 . 
policies tend to lose popularity or are replaced in office, the researchers found a "loud no" as the answer to both questions. 110 The opposite proved to be the case: when deficits are reduced, governments that follow a "cold shower" approach and focus on spending cuts may be rewarded at the ballot box. ${ }^{111}$ If anything, more radical fiscal adjustments were associated with a lower probability of a change in government. ${ }^{112}$ The probability of government survival increased during sharp adjustments that primarily relied on spending cuts, particularly those involving major components of government wages and transfers. ${ }^{113}$ Similarly, the nine OECD nations with persistent surpluses up until the Great Recession achieved surprising political success. As shown in Table 9, the governments in the nine elections were reelected in 63 percent of the twenty-four elections in the eight years prior to the Great Recession. By contrast, nations with the highest deficits during this year were reelected 40 percent of the time. More importantly, the governments in surplus nations had far greater success in elections following the Great Recession. Incumbent governments won in six of eight elections in the surplus group, but only won in one of the five elections in the deficit group.

110. Alberto Alesina, Roberto Perotti \& José Tavares, The Political Economy of Fiscal Adjustments, 1998 BROOKINGS PAPERS ON ECON. ACTIVITY 197, 198 (1998).

111. Id.

112. Id. at 231 .

113. Id. at 233 . 
Table 9: Electoral success of surplus v. deficit nations

\begin{tabular}{|c|c|c|c|c|}
\hline \multirow{2}{*}{ Country } & \multirow{2}{*}{$\begin{array}{c}\text { \# of times } \\
\text { surplus was } \\
\text { achieved (2000- } \\
\text { 2008) }\end{array}$} & \multicolumn{2}{|c|}{$\begin{array}{c}\text { \# of times } \\
\text { governing party } \\
\text { changed (2000- } \\
2008)\end{array}$} & \multirow{2}{*}{$\begin{array}{c}\text { Election after } \\
\text { GFC }\end{array}$} \\
\hline & & $\begin{array}{l}\text { Electio- } \\
\text { ns }\end{array}$ & $\begin{array}{l}\text { Change } \\
\text { in } \\
\text { Governm- } \\
\text { ent } \\
\end{array}$ & \\
\hline \multicolumn{5}{|c|}{ Surplus Nations } \\
\hline Australia & 9 & 3 & 1 & Incumbent won \\
\hline Canada & 6 & 4 & 1 & Incumbent won \\
\hline Denmark & 8 & 2 & 0 & Opposition won \\
\hline Finland & 9 & 2 & 2 & Opposition won \\
\hline Korea & 9 & 5 & 3 & $\begin{array}{l}\text { No election held } \\
\text { yet }\end{array}$ \\
\hline Luxemburg & 8 & 1 & 0 & Incumbent won \\
\hline $\begin{array}{l}\text { New } \\
\text { Zealand }\end{array}$ & 9 & 3 & 1 & Incumbent won \\
\hline Norway & 9 & 2 & 0 & Incumbent won \\
\hline Sweden & 7 & 2 & 1 & Incumbent won \\
\hline \multicolumn{5}{|c|}{ Deficit Nations } \\
\hline Greece & 0 & 2 & 1 & $\begin{array}{l}\text { Incumbent } \\
\text { won/lost }\end{array}$ \\
\hline Portugal & 0 & 2 & 0 & Opposition won \\
\hline Spain & 3 & 2 & 1 & Opposition won \\
\hline Italy & 0 & 2 & 3 & Opposition won \\
\hline Hungary & 0 & 2 & 1 & Opposition won \\
\hline
\end{tabular}

Sources: Nor. Soc. Sci. Data Serv., European Election Database, http://www.nsd.uib.no/ european_election_database/; Nor. Soc. Sci. Data Serv., The MacroData Guide-An

International Social Science Resource, http://www.nsd.uib.no/macrodataguide/topic2.html? code $=302 \&$ cat $=$ Government\%20statistics (last visited June 10, 2015).

Importantly, these governments also closed significant budget gaps while also winning reelection, in some cases several times over. While 
fiscal austerity was difficult and politically challenging, astute and savvy leaders developed effective political strategies to build consensus and gain public support.

Although some nations succeeded in their policies, fiscal austerity does not come naturally to any system. Rather, the nations that implemented austerity measures were acutely aware of the fragility of fiscal restraint and the political vulnerabilities of governments pressing for continued restraint after years of deficit reduction. Building on this understanding, in fact, these governments implemented sophisticated initiatives to build their case by tying fiscal austerity measures to broader national concerns and anxieties. In particular, each government explained that deficit reduction and surplus retention were critical to addressing the nation's concerns about the recent economic crises. ${ }^{114}$

\section{A. Factors Contributing to Politically Successful Campaigns for Fiscal Retrenchment}

It is important to understand what factors help influence governments to mount politically successful campaigns for fiscal retrenchment. Considerable thought has gone into explaining why fiscal choices are so politically unrewarding. It is time for policy analysts and political scientists to conduct qualitative and quantitative research to examine the other side of the political equation-how leaders can structure these choices so they can survive, and even thrive.

As noted earlier, conventional wisdom suggests that leaders have shortsighted time horizons, and the political rewards of consolidation are likely to be overshadowed by near-term political reaction. Research shows that voters are capable of making intertemporal comparisons and supporting policies requiring short-term deprivation. Leaders have proven adept at making the link between fiscal consolidation and economic outcomes that matter to voters, such as low inflation and growth. 115

Keech, among others, argues that political leaders have to exercise at least a modicum of economic foresight because voters judge them based on retrospective voting (i.e., how well the economy has done under the leader's term). Leaders are penalized if rising debt and deficits lead to higher interest rates, inflation, and currency crises. These factors

114. Paul L. Posner \& Jón Blöndal, Democracies \& Deficits: Prospects for Fiscal Responsibility in Democratic Nations, 25 GOVERnANCE: AN INT'L J. POL'Y ADMIN. \& INSTITUTIONS 11, 27 (2012).

115. See Adam Prezeworski, Public Support for Economic Reforms in Poland, 29 CoMP. PoL. STUD. 520, 540-41 (1996) (discussing citizens' perceptions of the government's success as a factor in their voting decisions). 
account for the history of budget balance and fiscal consolidations that have occurred in many democratic regimes. ${ }^{116}$

Indeed, savvy political leaders have proved adept at framing deficit reduction as an economic growth program. They are able to lay economic problems such as high interest rates and inflation at the doorstep of high deficits. 117 The sacrifices involved in fiscal consolidation must be justified by pointing to prospective economic gains in the near term, whether it be easing credit market pressures or staving off the potential for a full-scale exogenous debt crisis. Indeed, if the size and credibility of the package are impressive, the "announcement effect"118 creates a self-reinforcing virtuous cycle, prompting financial markets to lower interest rates at the outset when the consolidation package is established and enacted.

Of course, any democratically elected official has to be constantly aware of the public's views on fiscal policy. Leaders can take advantage of the broader public's ambivalence about fiscal policy and consolidation. Typically, the public does not like deficits but also has strong support for continuing current taxes and spending programs. These conflicting views change in relative salience over time, providing openings for leaders to mount campaigns. ${ }^{119}$

How do leaders reshape the focus of debates? By reframing what the debate is about. This means changing the definition of the issue by highlighting the salience of one facet or dimension over others. Shifting the focus of debates need not entail convincing the other side that they are wrong in an absolute sense. Rather, it calls for the less demanding task of shifting the relative priority of different values and priorities that most of us care about. ${ }^{120}$

For fiscal policy debates, this means that leaders need not convince the public that their attachment to low taxes or social security benefits are misplaced in some absolute sense. Rather, policy change occurs

116. William R. KeECH, ECONOMIC POLITICS: The COSTS OF DEMOCRACY 107 (1995).

117. See U.S. Gov'T ACCOUNTABILITY OFFICE, supra note 38, at 28-35 (describing the turning points in Fiscal Policy for several nations).

118. The announcement effect is defined as:

The impact on markets from the news that a change will occur at some future date. It can be used as a general term for the reaction to any development that affects trading, such as a change in dividend policy or a stock split. It is most often used, however, to describe investor reactions to changes in monetary policy, such as a hike or cut in a key interest rate level.

Announcement Effect, INVESTOPEDIA, http://www.investopedia.com/terms/a/announcmenteffect.asp (last visited June 2, 2015).

119. Posner, supra note 12 , at 23 .

120. Timothy J. Conlan, Paul L. Posner \& David R. Beam, The Pathways of Power: The Dynamics of National Policymaking 131 (2014). 
when leaders succeed in showing the consequences of these policy attachments for other values to which broader publics are equally attached, namely fiscal and economic sustainability.

\section{CONCLUSIONS}

\section{A. Analysis of Future Challenges}

Daunting challenges lie ahead in the next several decades for democratic nations and their leaders. Fiscal retrenchment calls for a level of sacrifice that tests the foresight and resolve of a democracy. Near-term economic pressures have combined with longer-term secular forces to prompt the need for periodic episodes of fiscal consolidation. As the role of government in the social and economic lives of nations has grown, so have the stakes of budgeting. Accordingly, the choices have become more difficult, even while the number of stakeholders and the pathways to power have become more diverse. Politics is far less predictable and decisionmaking far more open than ever before.

Notwithstanding these forces, the magnitude of the fiscal challenges has heightened the importance of early action and foresight in fiscal policymaking. The best way to effectively deal with the economic forces that aging societies face is to make timely decisions that have the broad support of as many interest groups and actors as possible. Making such decisions poses enormous difficulties, as summoning publics to support fiscal sacrifice is a task that carries liability for leaders in any democracy. There is no way to underestimate the difficulties this poses for democratically elected leaders. And there are certainly many cases where democratic nations-including our own-have failed to rise to this challenge.

The question facing democracies is whether there is a sustainable politics that can provide support and incentives for political leaders to make hard choices in a timely fashion. Traditional models of policymaking are generally based on the twin principles of incrementalism and negative feedback. ${ }^{121}$ Leading political scientists such as Charles Lindblom concluded that the policy process has a conserving bias stemming both from political interests as well as institutional routines that structure and channel change. ${ }^{122}$ In the United States, the Madisonian system's checks and balances reinforce a

121. Frank. R. Baumgartner \& Bryan D. Jones, Agendas and Instability in AMERICAN POLITICS 4-6 (1993).

122. See Michael T. Hayes, The Limits of Policy Change: Incrementalism, WORLDVIEW, AND THE RULE OF LAW 6, 40, 176 (2001). 
perception of a system where major change must overcome numerous hurdles, sometimes called veto points. ${ }^{123}$

Until recently, passing the federal budget was characterized as an incremental process. In the traditional works by Wildavsky and Fenno, budgeting at the federal level primarily focused on shifts in resources at the margin from the base. This characterization depicts a resource allocation process that corresponds to a largely pluralist world, where narrow interests prevail and where policy changes largely occur, if at all, only on the margin. ${ }^{124}$

Recent work suggests that budgeting is far from incremental; rather, the budgeting process is characterized by dramatic and episodic shifts in resources for major programs. Baumgartner and Jones find that budget decisions for policy areas can veer from several years of stability to sharp periods of rapid change, corresponding to elections, economic and social changes, and major reframing of policy issues. ${ }^{125}$

The stakes involved with budget decisions have grown exponentially as government's roles in the social and economic life of their nations have expanded in recent decades. While appropriations decisions still largely operate within the pluralist pathways, the calm world of appropriations has been supplanted by mandatory entitlements whose character does not lend themselves to marginal changes, particularly when small cuts from growing baselines prompt widespread mobilization. Wildavsky's later editions recognized this shift by noting that the consensual base for budgeting had been replaced by budgetary dissensus over fundamentals. ${ }^{126}$

\section{B. Multiplication of Pathways to Power}

The multiplication of arenas that incubate and mobilize broader publics to support policy reforms and fiscal changes alike reflect the presence of a more fluid and dynamic policy process. These multiple arenas draw on what the co-author and several colleagues have characterized as four "pathways to power": pluralist, partisan, expert,

123. See id. at 19 (discussing incremental change in U.S. policymaking and factors contributing to deviations from this pattern).

124. See Wildavsky, supra note 77 , at 136; RICHARD F. FENNo, THE POWER of THE PURSE: APPROPRIATIONS POLITICS IN CONGRESS 267 (1966).

125. See generally James L. True, Bryan D. Jones \& Frank R. Baumgartner, Punctuated-Equilibrium Theory: Explaining Stability and Change in Public Policymaking, in Theories of The Policy Process 155 (Paul A. Sabatier ed., 2007) (discussing the dynamics governing departures from incrementalism and stability in policymaking).

126. See generally AARon WILdAvsky \& NaOMI CAIDEN, THE NEW Politics of THE Budgetary Process 93-124 (2001) (analyzing the intensified polarization and unprecedented manifestations of dissensus occurring in the 1980s). 
and symbolic. ${ }^{127}$ In this model the authors characterize four pathways to power characterized by two dimensions-the scope and scale of mobilization (whether specialized or mass) and the method of mobilization (principally, whether interests or ideas were at play). These dimensions suggest that policies come to the agenda and enactment through four discrete pathways of power as shown in Table 10.

Table 10: The pathways to power

\begin{tabular}{|c|c|c|}
\hline $\begin{array}{c}\text { Scope of } \\
\text { mobilization / Basis } \\
\text { of mobilization }\end{array}$ & Narrow & Broad \\
\hline Interests & Pluralist & Partisan \\
\hline Ideas & Expert & Symbolic \\
\hline
\end{tabular}

The pluralist pathway was the political and institutional grounding for public choice theory and incrementalism, as the relevant interest groups and other specialized actors in appropriations committees and agencies exercised hegemonic influence and control over discrete budgetary areas, ranging from veterans to public health to transportation. ${ }^{128}$ In some respects, much of the pessimism over the potential for fiscal retrenchment and the adoption of policy reforms stems from the rather static view of the policy process as being captured by narrow pluralistic interests. 129

The other three pathways have emerged as alternative bases for mobilizing publics on behalf of fiscal and policy change. Party leaders have traditionally been conceived as the major broad-based change agents, capable, through leadership, of mobilizing broad publics to outflank and shift the framing of issues away from the narrow confines of pluralistic bastions. In the United States and several other nations, however, polarization has caused this pathway to lose vitality as a source of major policy change. Gridlock and stalemate provide little basis for fiscal reform or policy change in democratic systems.

127. See generally CONLAN, POSNER \& BEAM, supra note 120 (providing an in-depth analysis of the four distinct pathways to power and examining the interaction between each pathway and the dynamics of policymaking).

128. See generally JohN F. Cogan ET AL., THE BUdget Puzzle: Understanding FEDERAL SPENDING (1994) (analyzing budget policymaking from a "microbudgeting" approach that breaks the budget down into its distinct components to review each program or account).

129. See CONLAN, POSNER \& BEAM, supra note 120 , at 18. 
Idea-based pathways that have emerged in recent decades offer an alternative for reframing policy issues and providing new ways to change the political calculus of consent. Public officials have become increasingly attracted to symbolic budgetary proposals to position themselves on the "right side" of fiscal, tax, or entitlement policy issues. Ideas in this pathway are championed not for their technical adequacy but for their potential to appeal to widely shared values or moods, often providing deceptively simple or apparently costless approaches to wrenching budgetary choices. When issues fall into the expert pathway, professional knowledge and technical feasibility become the source of legitimacy against which all proposals are based. Experts' roles in the process are fortified by the growing need for credible numbers and models to understand increasingly complex relationships between federal programs, the economy, and performance outcomes.

Secular changes in institutions have promoted greater potential for pathway shifting in democratic systems than ever before. More competition among interest groups in the pluralist pathway, more media outlets vying for audience share in the symbolic pathway, greater presence and salience of experts, and more competition among elected officials anxious to use policy issues to fortify their standing with various publics have all heightened the potential for policy change. Greater competition among these actors prompts actors to switch pathways to gain strategic advantage.

In the United States at least, the increasing fluidity of the policy process prompted the adoption of major reforms in the fiscal arena as well as other policy domains. A diverse array of policy actors was able to break through the many obstacles of the U.S. system to achieve nonincremental reforms-without a crisis for the most part. Table 11 shows the inventory of domestic policy reforms achieved in the past thirty-four years in the U.S. system. 
Table 11: Crisis and policy reforms 1981-2010

1982 TEFRA

1983 Social Security

Reform

1986 Tax Reform

1988 Medicare

Catastrophy

1990 OBRA

1990 Clean Air Act

1993 NAFTA

1993 Deficit Red

1996 TANF

1996 Farm Reform

No

1996 Telecommunications No

Reform

1997 Balanced Budget Act No

2002 DHS

Yes

2002 Sarbanes-Oxley

Yes

2010 Health Reform No

2010 Financial Reform Yes

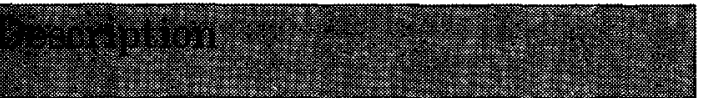

Undo Part of 1981 Reagan Tax Cuts

Save Social Security from trust fund depletion

Reagan initiated reform to broaden base of tax code

Provide seniors with catastrophic and drug coverage

Over $\$ 500$ billion in bipartisan deficit cuts stemming from bond market pressures

Cuts in acid rain through cap and trade

Bipartisan treaty negotiated by President Bush and pushed through by Clinton

Nearly $\$ 500$ billion in deficit reduction achieved by Clinton and Congressional Democrats

Welfare reform achieved through bipartisan change

Ramping down of subsidies through bipartisan change

Congressional action to spur competition in industry

Bipartisan deficit reduction includes tax cuts and Medicare cuts

Stand up DHS in response to $9 \cdot 11$

Financial market reforms in response to Enron crisis

President Obama's signature reform

Reforms instigated by 2008 financial crisis

Source: Developed by the author based on all of the major policy reforms enacted in the past thirty years across major policy areas. Policies chosen were those where major 
changes were ushered in causing reductions or shifts in policy benefits previously enjoyed by narrow-based interests. As such, these policies represent the difficult choices in U.S. policymaking. Policies excluded were such items as the Bush tax cuts or 2002 Farm Reform where the primary thrust was to restore or provide new benefits to specific interests. The list was developed based on that of "major" policy changes defined in DAVID MAYHEW, CONGRESS: THE ELECTORAL CONNECTION (1978) (examining the connection between Members of Congress' levels of engagement in major policy changes and the motivating goal of reelection).

Just as policy claimants have used symbolic and expert pathways to mobilize support for new entitlements and tax cuts, fiscal guardians and political leaders have proved equally adept at conscripting those arguments and mobilization strategies to make the case for fiscal consolidation and policy reform Fiscal consolidation strategies and arguments have gained strength thanks to the savvy use of more open policymaking processes to reach broader publics. Leaders have a greater chance to frame their case for fiscal austerity in terms that broad publics can support.

\section{Looking Ahead}

Given the high stakes involved with the democratic response to deficits, more research is needed to explore how democratic nations achieve fiscal reform. It is also important to better understand how such fiscal consolidation initiatives are thwarted and delayed. The conventional wisdom may be exactly right in predicting a difficult road for those who champion fiscal consolidation in the United States and elsewhere. Indeed, nations in Europe such as Greece and Portugal illustrate that procrastination in confronting fiscal challenges characterizes the initial response of many democracies facing incipient deficits.

Those who would predict frustration and gridlock over fiscal consolidation may be correct most of the time. But they are wrong at crucial times-and these are the times when democratic systems can quickly break through barriers to achieve significant fiscal progress and reform. Understanding when those turning points occur and how to promote politically sustainable shifts in fiscal policy are the central tasks facing democratic systems and their leaders. 


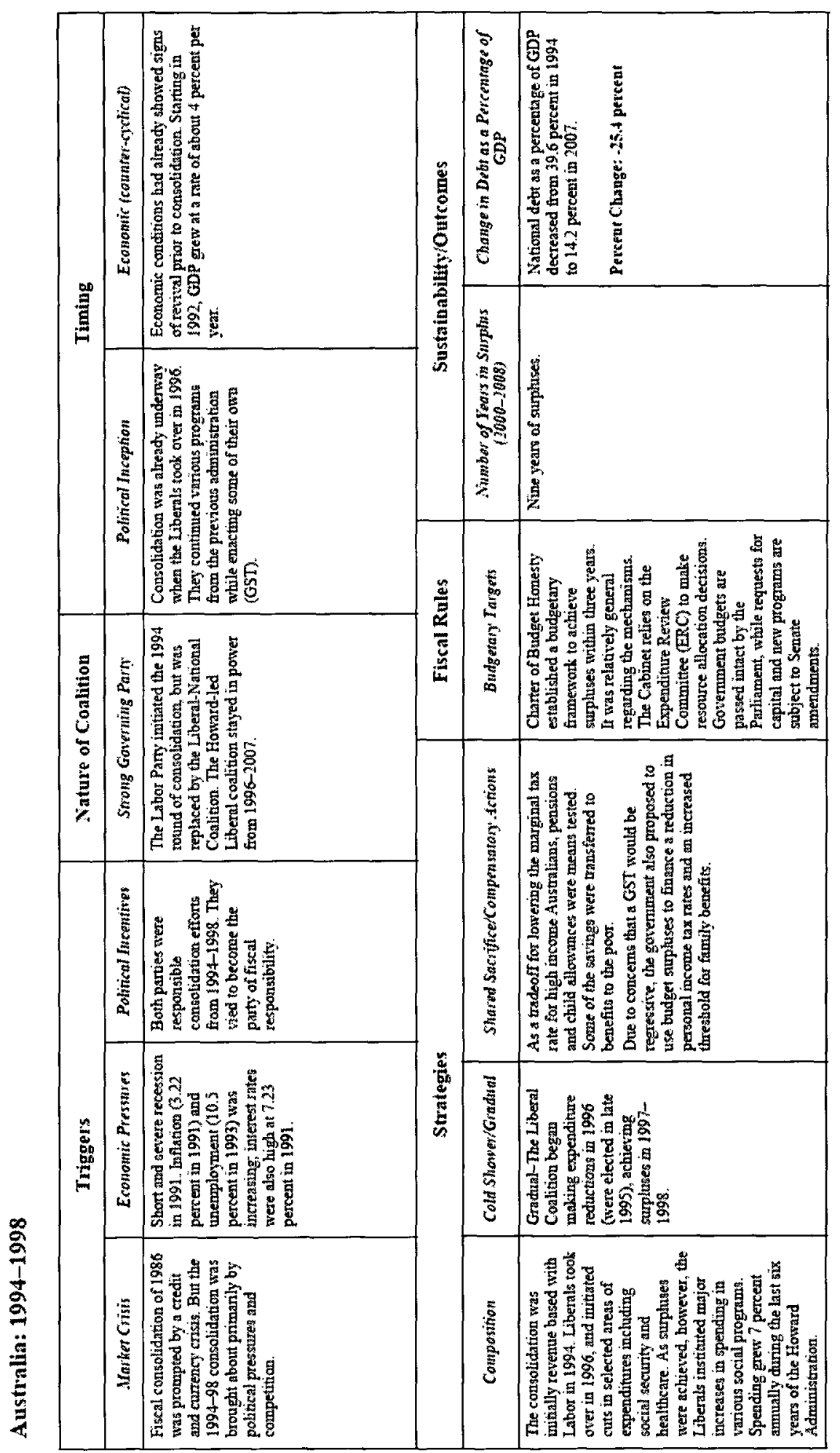




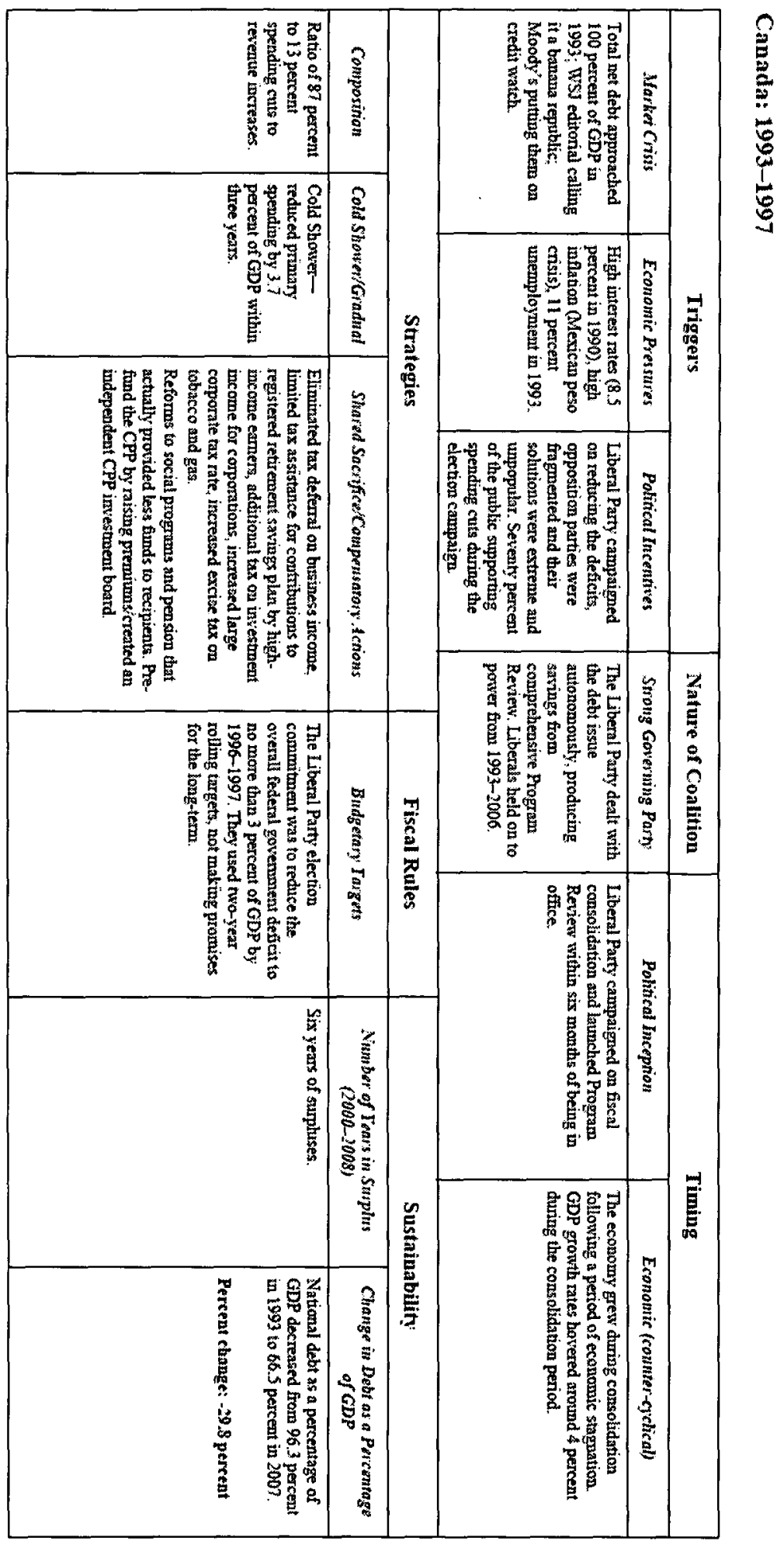




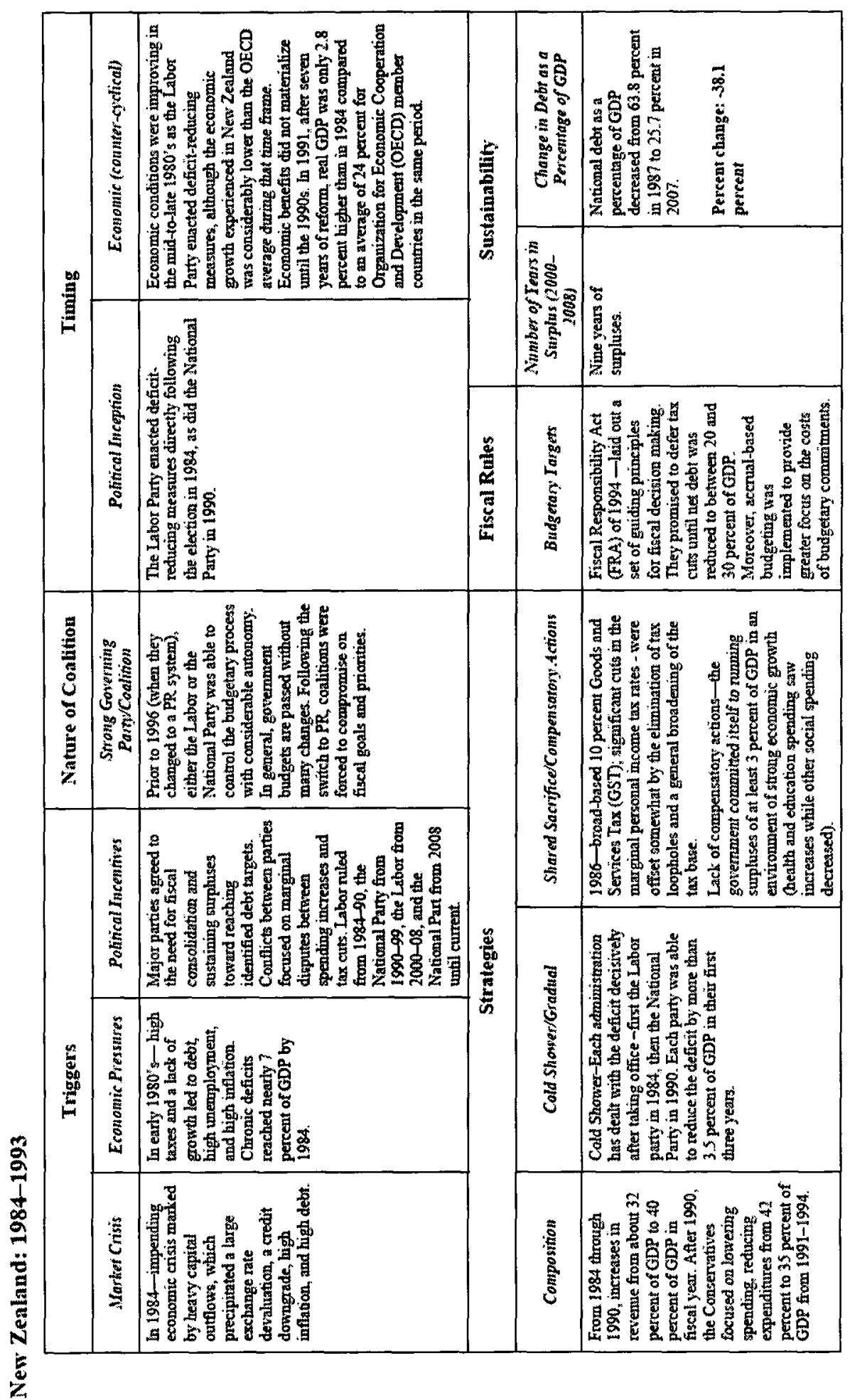




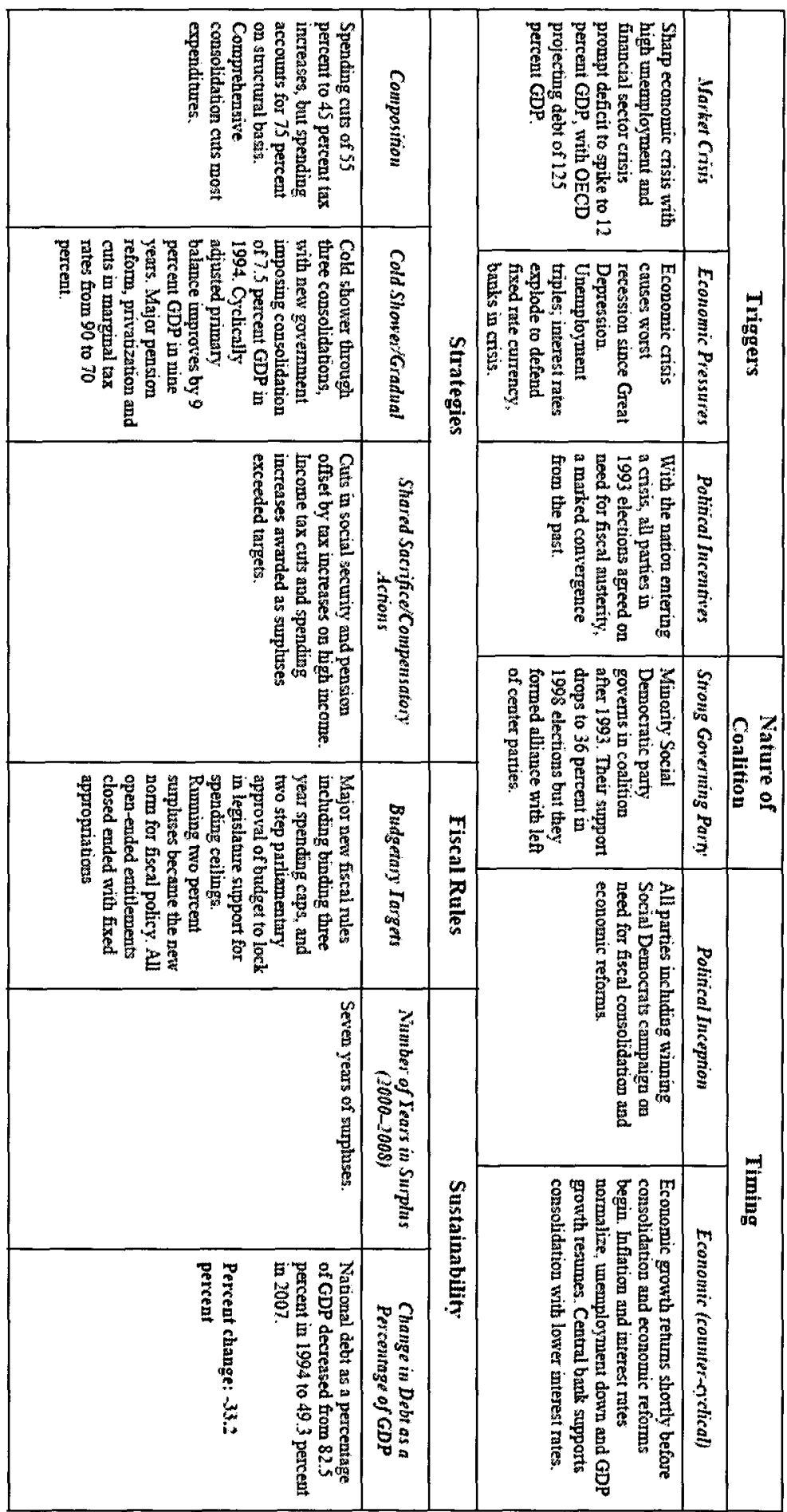




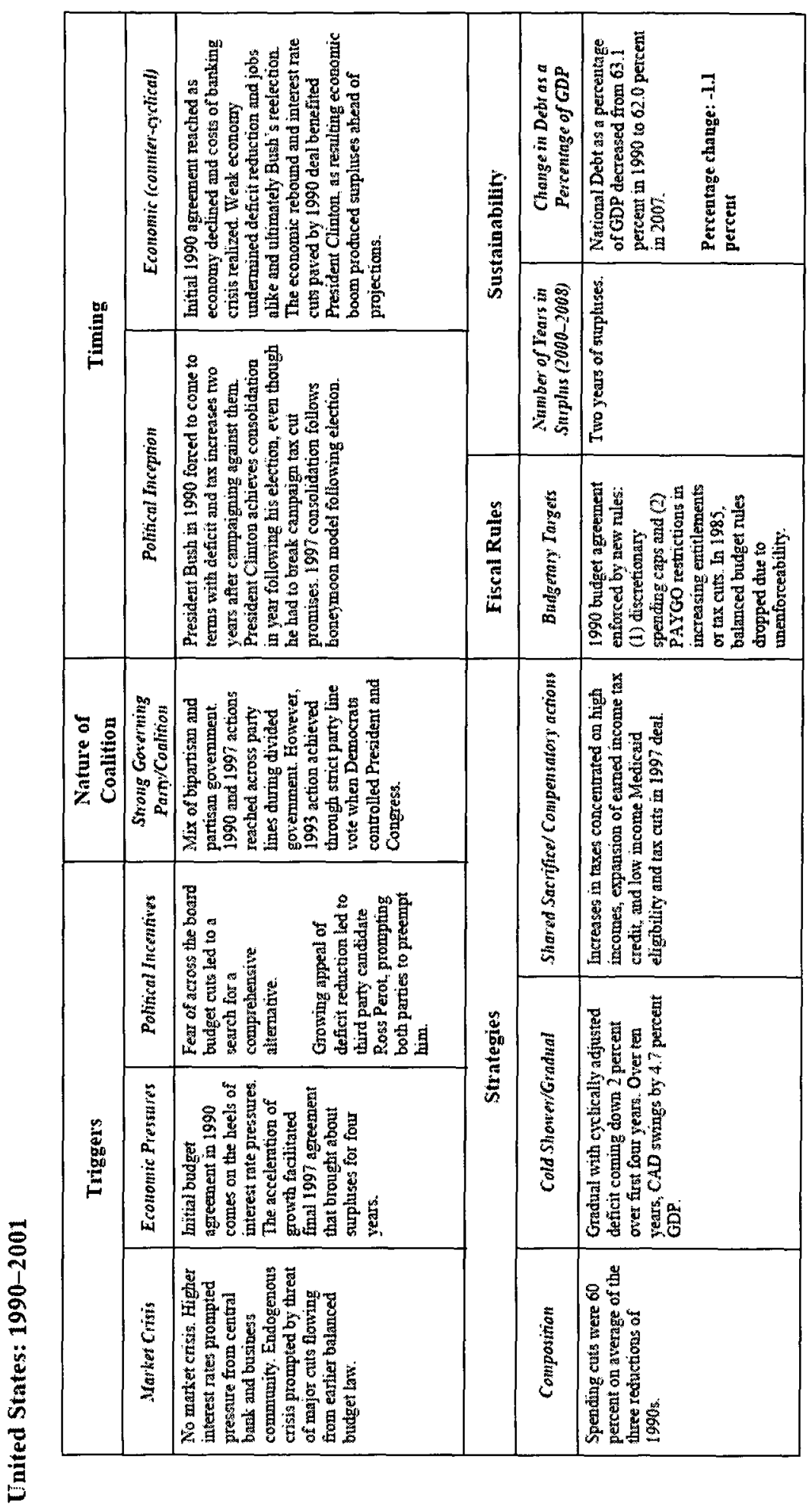

